\title{
Okul Öncesi Piyano Metotlarının Erken Çocukluk Dönemi Gelişim Basamakları Açısından İncelenmesi*
}

\section{An Analysis on the Preschool Piano Methods in terms of Early Childhood Development Stages}

\author{
Atakan Ertem \\ Arș. Gör., Pamukkale Üniversitesi, Eğitim Fakültesi, Güzel Sanatlar Eğitimi Bölümü \\ email: atakanertem@pau.edu.tr (DORCID ID: https://orcid.org/0000-0002-1483-3148
}

\section{Belir Tecimer}

Prof. Dr., Gazi Üniversitesi, Gazi Eğitim Fakültesi, Güzel Sanatlar Eğitimi Bölümü email: belir@gazi.edu.tr (DORCID ID: https://orcid.org/0000-0001-6485-4409

* Bu çalışma, “Okul Öncesi Piyano Metotlarının Erken Çocukluk Dönemi Gelişim Basamakları Açısından İncelenmesi” başlıklı yüksek lisans tezinden üretilmiştir.

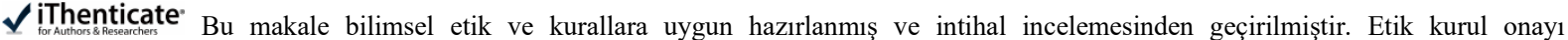
gerektirmemektedir.
\end{abstract}

Atıf (APA 7)/To cite this article

Ertem, A. ve Tecimer, B. (2021). Okul öncesi piyano metotlarının erken çocukluk dönemi gelişim basamakları açısından incelenmesi. Atatürk Üniversitesi Güzel Sanatlar Enstitüsü Dergisi, 27(47), 338-361. https://doi.org/10.35247/ataunigsed.933149

Makale Gönderim Tarihi/Received: 05/05/202

Makale Kabul Tarihi/Accepted: 24/08/2021

Makale Yayın Tarihi/Published: 28/10/202

Research Article / Araştırma Makalesi

\section{Öz}

$\mathrm{Bu}$ araştırma okul öncesi piyano metotlarının erken çocukluk dönemi gelișim basamakları açısından incelenmesini amaçlamaktadır. Araştırmadaki amaç, seçilen metotların belirlenen görsel, teknik, müzikal, teorik ve gelișimsel özelliklere ne kadar uyduğunu belirlemektir. Araştırmacı tarafindan seçilen okul öncesi piyano metotları doküman inceleme yöntemiyle değerlendirilmiștir. Görsel, teknik, müzikal, teorik ve gelişimsel yönden metotları incelemek amacıyla hazırlanan inceleme kriterleri uzman görüsüne sunulmuş ve yeniden düzenlenerek son halini almıştır. Seçkisiz olmayan örnekleme yöntemlerinden amaçlı örnekleme yöntemi ile seçilen Jane Smisor Bastien, Lisa Bastien ve Lori Bastien'a ait Bastiens' Invitation to Music, Nancy Faber ve Randall Faber'ın My First Piano Adventure, Nail Yavuzoğlu'nun Okul Öncesi Piyano Eğitimi, Yalçın İman'ın Okul Öncesi Çocuklar İcin Piyano Metodu inceleme kriterleri doğrultusunda piyano alanında uzman bes kiși tarafından incelenmiștir. Elde edilen verilerin analizinde içerik analizinden yararlanılmıştır. Uzmanların verdikleri cevaplar doğrultusunda elde edilen veriler frekans ve yüzde sayıları ile tablolar halinde sunulmuştur. Araştırmanın sonucunda, incelenen okul öncesi piyano metotları arasında eksiksiz, her anlamda cok iyi hazırlanmıs, mükemmel bir metodun olmadığı görülmüştür. İncelenen metotlardan Iman'ın metodu dıșındaki metotların okul öncesi döneme daha uygun planlanmış olduğu sonucuna varılmıştır. Araştırmada incelenen metotların bazı eksiklikleri olmasına rağmen okul öncesi piyano eğitiminde kullanılmaları uygun bulunmuş ve önerilmiştir.

Anahtar kelimeler: Piyano Eğitimi, Okul Öncesi Piyano Eğitimi, Okul Öncesi Piyano Metotları, Erken Çocukluk Gelişim Basamakları

\begin{abstract}
This research aims to examine preschool piano methods in terms of early childhood developmental stages. The research aims to determine how the selected methods fit the determined visual, technical, musical, theoretical, and developmental characteristics. Preschool piano methods selected by the researcher were evaluated by the document analysis method. The examination criteria prepared to examine the methods in terms of visual, technical, musical, theoretical, and developmental aspects were presented to the expert opinion and rearranged and took their final form. The methods in the research, Bastiens' Invitation to Music by Jane Smisor Bastien, Lisa Bastien and Lori Bastien, My First Piano Adventure by Nancy Faber and Randall Faber, Preschool Piano Education by Nail Yavuzoğlu, Piano Method for Preschool Children by Yalçn Iman, which were chosen by purposeful sampling method among non-random sampling methods were examined by five experts in the field. Content analysis was used in the analysis of the data obtained. The data obtained in line with the answers given by the experts were presented in tables with frequency and percentage numbers. As a result of the research, it was seen that there is no complete, well-prepared, and perfect method among the examined pre-school piano methods. It was concluded that methods other than Iman's method, among the examined methods, were more suitable for the pre-school period. Although the methods examined in the study have some shortcomings, their use in pre-school piano education has been found appropriate and recommended.
\end{abstract}

Keywords: Piano Training, Preschool Piano Training, Preschool Piano Methods, Early Childhood Development Stages

\section{Giriş}

Piyano eğitiminde okul öncesi piyano metotları son yıllarda çok önem kazanmaya ve bu metotların sayıları gün geçtikçe artmaya başlamıştır. Okul öncesi piyano metotları hem çocuk gelişiminde hem de ileriki piyano eğitimine zemin oluşturmak anlamında son derece etkilidir. Bu nedenle okul öncesi piyano metotlarının erken çocukluk dönemi gelişim basamaklarına uygun olarak hazırlanması ve uygun metotların piyano eğitimcileri tarafından seçilebilmesi oldukça önemlidir. 
Okul öncesi dönem, çocuklar için öğrenme ile gelişimin çok yoğun yaşandığı ve edinilen tecrübelerin daha sonraki yıllara yol gösterdiği dönemdir. Gelişimin büyük çoğunluğu hayatın ilk altı yılında tamamlanır. Bu yüzden gelişim alanlarının desteklenmemesi gibi bir durumda ileriki yıllarda telafi edilemeyecek olumsuz sonuçlar söz konusu olabilir (Kartal, 2007). Erken çocukluk kavramı Türkiye'de 0-72 ay çocukların eğitimlerini kapsar. Bu döneme erken çocukluk eğitimi veya okul öncesi eğitim denmektedir (Yaşar, 2009). Okul öncesi dönemdeki çocukların gelişim özelliklerine bakıldığı zaman bilişsel, dil, fiziksel, psikomotor, sosyal, duygusal, vb. gelişim basamaklarının olduğu görülmektedir.

Kişinin etrafındaki dünyayı öğrenmesini ve anlamasını sağlayan aktif zihinsel etkinliklerdeki gelişimlere bilişsel gelişim adı verilmektedir. Bilişsel gelişim dönemi bebeklikten yetişkinliğe kadar insanın dünyayı, çevreyi fark etme yollarının daha etkili ve kompleks hale gelme sürecidir. Bilişsel süreç dendiği zaman akla; bellek, düşünme, algılama gibi zihinsel bilgi işlem süreçleri gelmelidir.

Konuşma yeteneği, yani dil, insanın en önemli niteliklerinin başında gelir. İnsanın duygularını, düşüncelerini, isteklerini bütün ayrıntılarıyla açığa vurmasını, yaşamını sürdürmesini mümkün kılar. Müzik yolu ile dil gelişimine büyük katkı sağlanabilir. Arslan (2005)'a göre; özellikle şarkı ve tekerleme söyleme çalışmaları çocuğun dil gelişimini olumlu yönde etkiler. Çocuklar rahat söyleyemedikleri sözcükleri, şarkı sözü olarak düzenlenmiş melodilerle daha rahat söylerler.

Fiziksel gelişim bedenin boyca uzaması ve ağırlıkça artmasının yanında tüm sistemlerin olgunlaşması olarak ifade edilebilir. Doğum öncesi evreden başlayarak ölüme kadar devam eden bir süreçtir. Bedensel olarak büyüyen ve gelişen çocuğun hareket (motor) gelişimi de belli bir sırada olmaktadır. Bu gelişim alanında duyu, sinir ve kas sistemi birlikte çalışır (Aydoğan vd., 2015).

Motor gelişimin iki temel alanı bulunmaktadır. Bunlar; büyük kas gelişimi ve küçük kas gelişimidir. Çocuklarda öncellikle büyük kas becerileri gerektiren davranışlar (yürüme, koşma, vb.) görülür. Küçük kas gelişimi gerektiren ince motor beceriler (nesne kontrol becerileri, elin yönetimi, vb.) ise daha sonra gelişir (Bayhan ve Artan 2007).

Sosyal gelişimin başlangıcı bebekliğin ilk günlerine kadar gitmektedir. Bir bebeğin annesine olan bağımlılı̆̆ onun sosyal ilişkilerinin başlangıcıdır. Çocuk yürümeye ve konuşmaya başladığında sosyal çevresi genişlemektedir. Sosyal ve duygusal gelişimi birbirinden bağımsız düşünmek mümkün değildir. Çünkü çocuğun sosyal ilişkileri onun duygularını etkilediği gibi duygusal gelişimi de sosyal gelişimini doğrudan etkilemektedir.

Özellikle müziği ve piyanoyu sevdirme sürecinde öğretmenin rolü çok büyüktür. Müzik eğitimcileri bu erken yaş grubu için çeşitli müzikal deneyimlere sahip olabilmelidir (Uszler vd., 1991). Çocukları seven, kendini bu alana adamış, geliştirmiş ve geliştirmeye devam eden iyi bir öğretmen ile yapılacak dersler, şüphesiz ki okul öncesi dönemdeki çocuğa çok değerli şeyler katacak, çocuğun ilerleyen zamanda piyanodaki gelişimine katkıda bulunacaktır. Okul öncesi dönemde piyano eğitmeninin ilk hedefi çocuk açısından öğrenmeyi gerçekleştirebilmektir. Öğretmen, iyi bir öğrenmenin gerçekleşebilmesi için çocuklara elverişli bir çevre sağlayabilmelidir. Çocuk bütün duyularını kullanıp, deneyimleri ile ilişkileri keşfedip, küçük ve büyük kaslarını kullanabilmelidir (Banet, 1990). Tüm bu hedeflere ulaşmada çocukların yaşı ve fiziksel özelliklerine uygun bir eğitim müziği dağarı seçimi büyük öneme sahiptir.

Kaynak (2004)'a göre 5 ve 6 yaş grubu çocuklarla eğitime başlanırken çocukların öğrenme durumlarına göre piyano metodu seçmek başarıya ulaşmakta önemli bir etkendir. Öğretmenin yeni çıkan metotları sürekli takip etmesi ve yöntemler hususunda kendini geliştirmesi iyi bir eğitmen olabilmesi adına zorunludur.

Okul öncesi döneme yönelik hazırlanan piyano metotlarının, piyano odaklı oyun oynama, dans etme, şarkı söyleme, vb. etkinlikleri içermesi bu yaş grubu çocukların öncelikle piyanoyu sevmelerini daha sonra bu sevgiye dayalı olarak çalma etkinliklerine geçilmesini sağlayacak bir metot yazım yaklaşımıdır. Bu yöntemle hazırlanan metotların çocukların hem genel gelişimlerine hem de piyano eğitimi sürecine olumlu yönde katkı sağlayacağ söylenebilir (Ertem, 2019).

\subsection{Problem Durumu}

Piyano eğitiminde kullanılmak üzere yazılan birçok metot vardır ve hala yeni metotlar üretilmektedir. Bir kıyaslama yapıldığında 6 yaş ve üzeri için hazırlanmış çok sayıda metot olmasına rağmen, okul öncesi piyano metotlarının sayısı nispeten daha azdır.

Birçok kişi bu dönemin ne kadar değerli olduğunun, piyano eğitimine ne kadar önemli bir temel oluşturduğunun farkında değildir. Araştırmacı tarafından yapılan tarama sonucunda, Türkiye'de kullanılan ve sayıları 10'u geçmeyecek okul öncesi piyano metodu varken, dünya genelinde bu sayı yaklaşık olarak 50 civarlarındadır. Ancak, diğer taraftan bu metotların okul öncesi yaş grubuna uygun olup olmadığı sorusu eğitimcilerin kafasını karıştırmaktadır. 
Kaynak tarafından 2004 yılında ve Güven vd. tarafından 2012 yılında yapılan araştırmalarda, seçme metotlar teknik beceriler, müzikal ve görsel ögeler yönünden incelenmiştir. Bu çalışmaların yanı sıra Işıkdemir tarafından 2017 yılında, Öztopalan vd. tarafından 2015 yılında ve Çağlak ve Ercan tarafından 2017 yılında yapılan çalışmalarda da seçilen metotlar teknik, teorik, müziksel, görsel ve tipografik özellikler açısından incelenmiştir. Ancak bu araştırmalarda gelişim basamaklarının önemine pek değinilmemiş ve metotlar gelişimsel özellikler bakımından incelenmemiştir. Okul öncesi dönemde yaş grubuna uygun şekilde doğru planlanmış bir metotla piyanoya başlamış olan bir çocuğun ileriki piyano eğitiminde hali hazırda edindiği kazanımların çocuğun çabuk ilerlemesine 1şık tuttuğu ve bunun önemli olduğu düşünülmektedir.

Okul öncesi piyano eğitimi alanında çok az sayıda araştırma yapıldığı için, bu çalışma önem teşkil etmektedir. Bunun yanı sıra, bu araștırmada incelenen okul öncesi metotlarının özellikle erken çocukluk dönemi gelișim basamaklarına uygun olup olmadığının saptanması gerekli görülmüştür. Piyano eğitimcilerinin bu yaş grubu için doğru metotlar kullanabilmesi amacıyla, bu araştırma kapsamında seçilmiş olan 2'si yabanc1, 2'si yerli olmak üzere 4 okul öncesi piyano metodunun çocukların gelişim basamaklarına uygunluk durumu bu araştırmanın problemini oluşturmaktadır.

\section{Yöntem}

\subsection{Araştırmanın Modeli}

Okul öncesi piyano metotlarının erken çocukluk dönemi gelişim basamakları açısından incelenmesini amaçlayan bu araştırmada nitel araştırma yöntemi kullanılmıştır. Nitel araştırmalar; gözlem, görüşme ve doküman analizi gibi nitel veri toplama yöntemlerinin kullanıldığı, algıların ve olayların doğal ortamda gerçekçi ve bütüncül bir biçimde ortaya konmasına yönelik nitel bir sürecin izlendiği araştırmalar olarak tanımlanabilir. Nitel araştırma yöntemlerinden doküman incelenmesi tercih edilmiştir. Doküman incelemesi, araştırılması hedeflenen olgu veya olgular hakkında bilgi içeren yazılı materyallerin analizini kapsar (Yıldırım ve Şimşek, 2016).

Bu çalışmada görsel, teknik, müzikal, teorik ve gelişimsel yönden metotları incelemek amacıyla hazırlanan inceleme kriterleri uzman görüşüne sunulmuş ve yeniden düzenlenerek son halini almıştır. Seçkisiz olmayan örnekleme yöntemlerinden amaçlı örnekleme yöntemi ile seçilen 4 metot hazırlanan bu inceleme kriterleri doğrultusunda piyano eğitimi alanındaki 5 uzman tarafından analiz edilmiştir. Uzmanların hepsinin uzmanlık alanları piyano eğitimidir. Ortalama çalışma sürelerine bakıldığında biri 5 yıldır, dördü ise 15 yılı aşkındır Üniversitelerin Müzik Eğitimi Anabilim Dalı'nda alana hizmet etmektedir.

\subsection{Evren ve Örneklem}

$\mathrm{Bu}$ araştırmada nitel araştırmalarda kullanılan seçkisiz olmayan örnekleme yöntemlerinden amaçlı örnekleme yönteminden faydalanılmıştır. Amaçlı örnekleme yöntemi zengin bilgiye sahip olduğu düşünülen durumların derinlemesine çalışılmasına olanak vermektedir (Yıldırım ve Şimşek, 2016). Araştırmanın evrenini okul öncesi piyano metotları oluşturmaktadır. Araştırmanın örneklemini ise zengin bilgiye sahip olduğu düşünülen durumların derinlemesine çalışılmasına olanak veren amaçlı örnekleme yöntemine göre seçilen 4 adet okul öncesi piyano metodu oluşturmuştur.

Araştırmada incelenecek metotlar aşağıdaki gibidir:

a) Bastien, J. S., Bastien, L. ve Bastien, L. (1993). Bastiens' Invitation to Music:

- Piano Party A,

- Piano Party B.

b) Faber, N. ve Faber, R. (2006). My First Piano Adventure:

- Lesson Book A,

- Lesson Book B,

- Lesson Book C.

c) Yavuzoğlu, N. (2017). Okul Öncesi Piyano Eğitimi.

d) İman, Y. (2016). Okul Öncesi Çocuklar İçin Piyano Metodu.

\subsection{Veri Toplama Aracı}

Araştırmada okul öncesi piyano metotları hakkında bilgi toplamak için internette ve çeşitli kütüphanelerde literatür taraması yapılmıştır. Elde edilen literatürden seçilen 4 metot, erken çocukluk dönemi gelişim basamakları açısından incelenmiştir.

Piyano metotlarına ait görsel, teknik, müzikal, teorik ve gelişimsel özellikleri içeren bir ölçek araştırmacı tarafından düzenlenmiş ve piyano eğitimi alanında 3, okul öncesi eğitimi alanında 2 , okul öncesi müzik eğitimi alanında 2 olmak üzere toplam 7 uzman eşliğinde ölçeğin kapsam geçerliliği yapılmıştır. Uzmanlardan, seçilen metotları incelemek üzere belirlenen maddelerin uygun olup olmadıklarıyla ilgili görüş belirtmeleri istenmiştir. Uzmanların ortak görüşe varmadığı maddeler tablolardan çıkarılmış, uyarlanmış ve ölçeğe son hali verilmiştir. 
Ölçekte 5'li Likert tip (Kesinlikle katılmıyorum, Katılmıyorum, Kararsızım, Katılıyorum, Kesinlikle Katılıyorum) kullanılmıştır. Görsel özelliklerde 6, teknik özelliklerde 8, müzikal-teorik özelliklerde 14, gelişimsel özelliklerde 24 (fiziksel gelişim 6, bilişsel gelişim 13, sosyal ve duygusal gelişim 5) madde kullanılmıştır. Seçilen metotlar hazırlanan ölçek soruları doğrultusunda piyano eğitiminde alanında uzman 5 kişi tarafından analiz edilmiştir.

\subsection{Verilerin Analizi}

Ölçek maddelerine uzmanların verdikleri cevaplar tablolaştırılmış, yüzde ve frekans sayılarına yer verilmiştir. Uzmanların metotlara ait görsel, teknik, müzikal, teorik ve gelişimsel özellikleri değerlendirmeleri sonucunda ortaya çıkan benzerlikler ve farklılıklara değinilerek metotların amaca uygunluğu, başarı düzeyleri değerlendirilmiştir.

\section{Bulgular}

Okul öncesi piyano metotlarının erken çocukluk dönemi gelişim basamakları açısından incelenmesini amaçlayan bu araştırmaya ait bulgular aşağıda verilmiştir.

Tablo 1

Jane Smisor Bastien, Lisa Bastien ve Lori Bastien - Bastiens' - Invitation to Music: Piano Party A Metoduna Ait Görsel Özellikler

\begin{tabular}{lllll}
\hline Görsel Özellikler & - & - & - & - \\
\end{tabular}

Tablo 1'de görüldüğü üzere uzmanların tamamının görsel özelliklerdeki kriterlere katılıyorum ve kesinlikle katılıyorum cevaplarını verdikleri görülmektedir. Metodun dıș kapağı ve sayfa düzeni güzel planlanmıștır. Nota, ölçü, dizek, sus, vb. bütün işaretlerin büyüklükleri yanı sıra kullanılan resim ve fotoğraflar hedef kitleye uygun seçilmiştir. Kullanılan resim ve fotoğraflar renk, boyut, vb. kıstaslar açısından ilgi çekicidir. Kullanılan yazı karakterleri, punto gibi tipografik özellikler de hedef kitleye uygun seçilmiştir. Buna göre Piano Party A kitabının bütün görsel özelliklerinin hedef kitleye uygun olduğu belirlenmiştir.

Tablo 2

Jane Smisor Bastien, Lisa Bastien ve Lori Bastien - Bastiens' - Invitation to Music: Piano Party A Metoduna Ait Teknik Özellikler

$$
\text { 禀芜 }
$$

\begin{tabular}{|c|c|c|c|c|c|c|c|c|c|c|}
\hline Doğru parmak, el, bilek, dirsek duruşları ile ilgili bilgiler verilmiş. & 4 & 80 & 1 & 20 & - & - & - & - & - & - \\
\hline Piyano başında doğru oturuş ve duruş ile ilgili bilgiler verilmiş. & 5 & 100 & - & - & - & - & - & - & - & - \\
\hline Doğru parmak numaraları belirli aralıklarla hatırlatılmış. & - & - & - & - & - & - & 1 & 20 & 4 & 80 \\
\hline İki elin birlikte kullanımına yer verilmiştir. & - & - & - & - & - & - & - & - & 5 & 100 \\
\hline Bağl1 - kesik çalma ile ilgili çalışmalar yapılmış. & 5 & 100 & - & - & - & - & - & - & - & - \\
\hline Çift ses çalışmalarına yer verilmiş. & 5 & 100 & - & - & - & - & - & - & - & - \\
\hline Üç ses - akor çalışmalarına yer verilmiş. & 5 & 100 & - & - & - & - & - & - & - & - \\
\hline Dizi çalışmaları ve parmak geçişlerine yer verilmiş. & 5 & 100 & - & - & - & - & - & - & - & - \\
\hline
\end{tabular}

Tablo 2'de uzmanların verdikleri cevaplar doğrultusunda Piano Party A kitabının teknik özelliklerinin hedef kitleye çoğunlukla uyumlu olmadığ1 görülmektedir. Metot boyunca doğru parmak, el, bilek, dirsek duruşları ve piyano başında doğru oturuş, duruş ile ilgili bilgilere rastlanılmamaktadır. Buna rağmen doğru parmak numaraları belirli aralıklarla hatırlatılmış ve iki elin birlikte kullanımına yer verilmiştir. Metotta bağlı - kesik çalma, çift ses çalışmaları, üç ses - akor çalışmaları, dizi çalışmaları ve parmak geçişlerine yer verilmemiştir. 


\section{Tablo 3}

Jane Smisor Bastien, Lisa Bastien ve Lori Bastien - Bastiens' - Invitation to Music: Piano Party A Metoduna Ait Müzikal ve Teorik Özellikler

Müzikal ve Teorik Özellikler

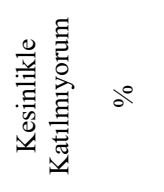

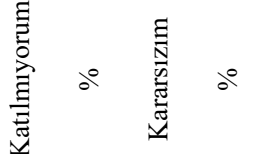

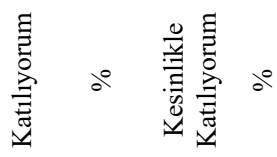

İçindekiler veya öneriler kısmı ile öğretmen yönlendirilmiş.

Temel müzik bilgilerine yer verilmiş.

Hedef kitleye uygun nota öğretimi seçilmiş.

Çeşitli bestecilerin eserlerine yer verilmiş.

Besteci ve dönemler hakkında bilgiler verilmis.

Metot sistematik, sıralı ve planlı bir şekilde tasarlanmış.

Öğretmen eşliğine yer verilmiş.

Dört el çalıșmalarına yer verilmiş.

Doğaçlama çalışmalara yer verilmiş.

Nota isimleri öğretilmiș.

Öğretilen notalar, anahtarlar, suslar, nüans terimleri, hız terimleri vb.

müzik bilgileri boyama, çizim gibi etkinliklerle pekiştirilmiş.

Metodun sonunda öğrenciye sertifika verilmiş.

Metotla birlikte CD eki verilmiş.

Metotla paralel çalıșma - ödev kitabı tasarlanmıș.

\begin{tabular}{cccccccccc}
- & - & - & - & - & - & 1 & 20 & 4 & 100 \\
- & - & - & - & - & - & 2 & 40 & 3 & 60 \\
- & - & - & - & - & - & 5 & 100 & - & - \\
5 & 100 & - & - & - & - & - & - & - & - \\
5 & 100 & - & - & - & - & - & - & - & - \\
- & - & - & - & - & - & 3 & 60 & 2 & 40 \\
5 & 100 & - & - & - & - & - & - & - & - \\
- & - & - & - & 1 & 20 & 4 & 80 & - & - \\
- & - & - & - & - & - & - & - & 5 & 100 \\
- & - & - & - & - & - & 2 & 40 & 3 & 60 \\
- & - & - & - & - & - & - & - & 5 & 100 \\
5 & 100 & - & - & - & - & - & - & - & - \\
- & - & - & - & - & - & - & - & 5 & 100 \\
\hline
\end{tabular}

Tablo 3’te uzmanların verdikleri cevaplar doğrultusunda Piano Party A kitabının müzikal ve teorik özelliklerinin hedef kitleye uygun olduğu görülmektedir. Kitapta içindekiler veya öneriler kısmı ile öğretmene yönlendirme yapılmıştır. Temel müzik bilgilerine yer verilmiştir ve hedef kitleye uygun nota öğretimi seçilmiştir. Metotta çeşitli bestecilerin eserlerine, besteci ve dönemler ile ilgili bilgilere yer verilmemiştir. Metot sistematik, sıralı ve planlı bir şekilde tasarlanmıştır. Öğretmen eşliklerine çeşitli parçalarda yer verilmiştir. Dört el çalışmalarına yer verilmemiş̧ir. Doğaçlama çalışmalara yer verilmiş, nota isimleri öğretilmiştir ve az da olsa öğretilen notalar, anahtarlar, suslar, nüans terimleri, hız terimleri, vb. müzik bilgileri boyama ve çizim gibi etkinliklerle pekiştirilmiş̧ir. Metodun sonunda öğrenciye bir sertifika verilecektir. Metotla paralel çalışma - ödev kitabı tasarlanmıştır. Ancak metotla birlikte CD eki verilmemiştir. Günümüz teknoloji çağında çocuğun evde CD veya web tabanlı bir uygulama yoluyla dinleme, çalma gibi pekiştirme çalışmaları yapması beklenmektedir. Bu metotta CD eki veya web tabanlı bir uygulama olmaması büyük bir eksiklik olarak göze çarpmaktadır.

Tablo 4

Jane Smisor Bastien, Lisa Bastien ve Lori Bastien - Bastiens' - Invitation to Music: Piano Party A Metoduna Ait Gelişimsel Özellikler

\section{Gelișimsel Özellikler}

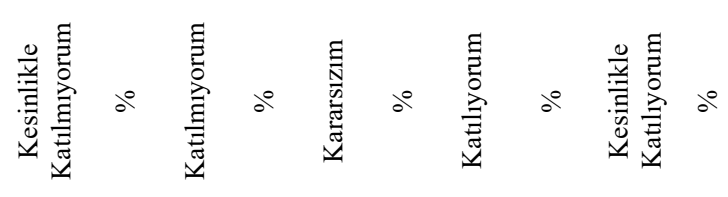

\section{Fiziksel Gelişim Özellikleri}

Çocuğun piyano başında oturuşu ile ilgili kas, iskelet sağlığını koruyucu uyarılar yapılmış ve ayağın altına tabure koyulması sağlanmıştır.

Çocukların ellerini yumruk yaptırarak tuşlar üzerinde etkinlikler yapılmıştır.

Çocukların daha güçlü olan 1 ve 2 numaraları parmaklarını kullandığı etkinliklere daha fazla yer verilmiştir.

Çocukların daha zayıf olan 4 ve 5 numaraları parmaklarının kullanımı ilerleyen etkinliklerde verilmiștir.

Çocukların görme becerilerine uygun olarak küçük ve ayrıntılı figürlerden kaçılmıș, büyük figürlere yer verilmiș.

Renk seçimi ve tonlamasında karmaşık olmayan bir yaklaşım izlenmiștir.

$\begin{array}{llllllllll}4 & 80 & 1 & 20 & - & - & - & - & - & - \\ - & - & - & - & - & - & 1 & 20 & 4 & 80 \\ - & - & - & - & - & - & 1 & 20 & 4 & 80 \\ - & - & - & - & - & - & 1 & 20 & 4 & 80 \\ - & - & - & - & - & - & - & - & 5 & 100 \\ - & - & - & - & - & - & 1 & 20 & 4 & 80\end{array}$

\section{Bilișsel Gelişim Özellikleri}

Piyano ile arkadaş olmaya yönelik temalar işlenmiștir.

Dil gelişimine fayda sağlayacak çalışmalara yer verilmiştir.

Dizeksiz nota eğitimi ile başlamıştır.

Sade ve dikkat dağıtmayan sayfa planlamaları yapılmıştır.

Etkinliklere başlarken eski konulara yer verilmiştir.

Etkinlik sonlarında sonraki etkinliklere hazırlayıcı çalışmalar yapılmıştır.

\begin{tabular}{cccccccccc}
- & - & - & - & 1 & 20 & 2 & 40 & 2 & 40 \\
- & - & - & - & - & - & 2 & 40 & 3 & 40 \\
- & - & - & - & - & - & - & - & 5 & 100 \\
- & - & 1 & 20 & 1 & 20 & 3 & 60 & - & - \\
- & - & 1 & 20 & 1 & 20 & 2 & 40 & 1 & 20 \\
\hline
\end{tabular}


Tablo 4'ün devamı

\begin{tabular}{|c|c|c|c|c|c|c|c|c|c|c|}
\hline Bilişsel Gelişim Özellikleri & 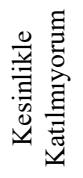 & $d^{\circ}$ & 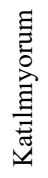 & $a^{\circ}$ & 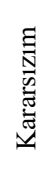 & $a^{0}$ & 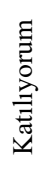 & $\partial^{0}$ & 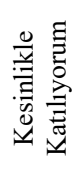 & $a^{\circ}$ \\
\hline $\begin{array}{l}\text { İşlenilen etkinlikler doğrultusunda evde çalışılmak üzere alıştırmalara } \\
\text { yer verilmiştir. }\end{array}$ & - & - & 2 & 40 & - & - & 3 & 60 & - & - \\
\hline Etkinliklerde müzik kavramları somutlaştırılmıştır. & - & - & - & - & - & - & 1 & 20 & 4 & 80 \\
\hline $\begin{array}{l}\text { Nota saplarının yerlerinin değişmesi, sağ ve sol el geçişleri, aynı } \\
\text { anlama gelen farklı işaretlerin kullanılması vb. konularda açıklamalar } \\
\text { yapılmıștır. }\end{array}$ & 1 & 20 & 2 & 40 & 2 & 40 & - & - & - & - \\
\hline $\begin{array}{l}\text { Okul öncesi eğitim ilkelerinden "basitten karmaşığa" ilkesine uygun } \\
\text { bir ilerleme ele alınmıştır. }\end{array}$ & - & - & - & - & - & - & 1 & 20 & 4 & 80 \\
\hline $\begin{array}{l}\text { Okul öncesi eğitim ilkelerinden "bilinenden bilinmeyene" ilkesine } \\
\text { uygun bir ilerleme ele alınmıştır. }\end{array}$ & - & - & - & - & - & - & 1 & 20 & 4 & 80 \\
\hline $\begin{array}{l}\text { Okul öncesi eğitim ilkelerinden "somuttan soyuta" ilkesine uygun bir } \\
\text { ilerleme ele alınmıştır. }\end{array}$ & - & - & - & - & - & - & 1 & 20 & 4 & 80 \\
\hline $\begin{array}{l}\text { Okul öncesi eğitim ilkelerinden "nesnellik ve açıklık" ilkesine uygun } \\
\text { bir ilerleme ele alınmıștır. }\end{array}$ & - & - & - & - & - & - & 1 & 20 & 4 & 80 \\
\hline \multicolumn{11}{|l|}{ Sosyal ve Duygusal Gelișim Özellikleri } \\
\hline $\begin{array}{l}\text { Çocuğu piyano başında sıkmadan, çocuğun canını acıtacak kadar } \\
\text { parmaklarını yormadan, onu mutlu edip eğlendirecek özelliklere } \\
\text { sahiptir. }\end{array}$ & - & - & 1 & 20 & - & - & - & - & 4 & 80 \\
\hline $\begin{array}{l}\text { Öğretmeniyle veya piyano dersi alan başka bir arkadaşıyla birlikte } \\
\text { çalma etkinliklerine yer verilmiştir. }\end{array}$ & - & - & - & - & - & - & 1 & 20 & 4 & 80 \\
\hline $\begin{array}{l}\text { Doğaçlama, birlikte çalma vb. etkinliklerle çocuğun girişkenliğini öne } \\
\text { çıkaracak çalışmalara yer verilmiştir. }\end{array}$ & - & - & 1 & 20 & - & - & 1 & 20 & 3 & 60 \\
\hline $\begin{array}{l}\text { Metot aileyi öğrenme sürecine dahil eder ve çocuğun evde düzenli } \\
\text { çalışması ile ilgili aile denetimi istenmiştir. }\end{array}$ & - & - & - & - & 1 & 20 & 3 & 60 & 1 & 20 \\
\hline $\begin{array}{l}\text { Oyun gelişimi ve yaratıcılığı destekleyen çocuk merkezli etkinliklere } \\
\text { yer verilmiştir. }\end{array}$ & - & - & - & - & - & - & 2 & 40 & 3 & 60 \\
\hline
\end{tabular}

Tablo 4'te uzmanların verdikleri cevaplar doğrultusunda Piano Party A kitabının gelişimsel özelliklerinin hedef kitleye çoğunlukla uyumlu olduğu görülmektedir. Fiziksel gelişim özelliklerine bakıldığında kitapta; çocuğun piyano başında oturuşu ile ilgili kas, iskelet sağlığını koruyucu uyarılara ve ayağın altına tabure koyulması ile ilgili herhangi bir bilgilendirmeye rastlanmamıştır. Çocukların ellerini yumruk yaptırarak tuşlar üzerinde etkinlikler yaptırıldığı, çocukların daha güçlü olan 1 ve 2 numaraları parmaklarını kullandığı etkinliklere daha fazla yer verildiği ve bu doğrultuda çocukların daha zayıf olan 4 ve 5 numaraları parmaklarının kullanımlarına ilerleyen etkinliklerde verildiği gözlemlenmektedir. Çocukların görme becerilerine uygun olarak küçük ve ayrıntılı figürlerden kaçıldığı ve büyük figürlere yer verildiği, renk seçimi ve tonlamasında karmaşık olmayan bir yaklaşım izlendiği görülmüştür. Bilişsel gelişim özellikleri ele alındığında kitapta; piyano ile arkadaş olmaya yönelik temaların işlendiği, dil gelişimine fayda sağlayacak çalışmalara yer verildiği, dizeksiz nota eğitimine yer verildiği ve dikkat dağıtmayan sayfa planlamaları yapıldığı görülmektedir. Etkinlik başlarında eski konuların tekrarı, etkinlik sonlarında yeni konuya hazırlayıcı çalışmalara ve işlenilen etkinlikler doğrultusunda evde çalışılmak üzere alıştırmalara yer verilmiştir. Etkinliklerde müzik kavramları somutlaştırılmıştır. Nota saplarının yerlerinin değişmesi, sağ ve sol el geçişleri, aynı anlama gelen farklı işaretlerin kullanılması vb. konuların çoğunda açıklama yapılmamıştır. Okul öncesi eğitim ilkelerinden "basitten karmaşığa", "bilinenden bilinmeyene", "somuttan soyuta", "nesnellik ve açıklık" ilkelerine uygun bir ilerleme ele alınmıştır.

Tablo 5

Jane Smisor Bastien, Lisa Bastien ve Lori Bastien - Bastiens' - Invitation to Music: Piano Party B Metoduna Ait Görsel Özellikler

\begin{tabular}{|c|c|c|c|c|c|c|c|c|c|c|}
\hline Görsel Özellikler & 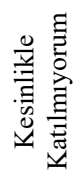 & $a^{\circ}$ & 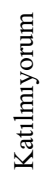 & $0^{0}$ & 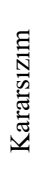 & $\partial^{\circ}$ & 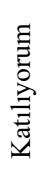 & $\partial^{\circ}$ & 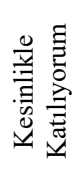 & $\partial^{\circ}$ \\
\hline Metodun diş kapağı güzel planlanmış. & - & - & - & - & - & - & 3 & 60 & 2 & 40 \\
\hline Metodun sayfa düzeni planlaması güzel yapılmış. & - & - & - & - & - & - & 3 & 60 & 2 & 40 \\
\hline $\begin{array}{l}\text { Nota, ölçü, dizek, sus, vb. bütün işaretlerin büyüklüğü hedef kitleye } \\
\text { uygun planlanmış. }\end{array}$ & - & - & - & - & - & - & 1 & 20 & 4 & 80 \\
\hline Kullanılan resim ve fotoğraflar hedef kitleye uygun seçilmiş. & - & - & - & - & - & - & 2 & 40 & 3 & 60 \\
\hline $\begin{array}{l}\text { Kullanılan resim ve fotoğraflar renk, boyut, vb. kıstaslar açısından ilgi } \\
\text { çekici. }\end{array}$ & - & - & - & - & - & - & 1 & 20 & 4 & 80 \\
\hline $\begin{array}{l}\text { Kullanılan yazı karakterleri, punto gibi tipografik özellikler hedef } \\
\text { kitleye uygun seçilmiș. }\end{array}$ & - & - & - & - & - & - & 2 & 40 & 3 & 60 \\
\hline
\end{tabular}


Tablo 5'te görüldüğü üzere uzmanlar Piano Party B kitabının bütün görsel özelliklerinin hedef kitleye uyduğu görüşünde birleşmektedirler. Metodun dış kapağı ve sayfa düzeni planlaması göze hitap etmektedir. Nota, ölçü, dizek, sus, vb. bütün işaretlerin büyüklükleri yaş grubuna uygundur. Kullanılan resim ve fotoğraflar hedef kitleye uygun seçilmiştir. Kullanılan resim ve fotoğraflar renk, boyut, vb. kıstaslar açısından çocuğun ilgisini çekecek şekildedir. Kullanılan yazı karakterleri, punto gibi tipografik özellikler de hedef kitleye uygun seçilmiştir.

Tablo 6

Jane Smisor Bastien, Lisa Bastien ve Lori Bastien - Bastiens' - Invitation to Music: Piano Party B Metoduna Ait Teknik Özellikler

\begin{tabular}{|c|c|c|c|c|c|c|c|c|c|c|}
\hline Teknik Özellikler & 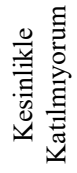 & $\Delta^{\circ}$ & 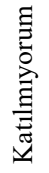 & $\partial^{\circ}$ & 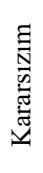 & $\partial^{\circ}$ & 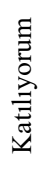 & $\partial^{\circ}$ & 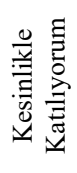 & $\partial^{\circ}$ \\
\hline Doğru parmak, el, bilek, dirsek duruşları ile ilgili bilgiler verilmiş. & 5 & 100 & - & - & - & - & - & - & - & - \\
\hline Piyano başında doğru oturuş ve duruş ile ilgili bilgiler verilmiş. & 5 & 100 & - & - & - & - & - & - & - & - \\
\hline Doğru parmak numaraları belirli aralıklarla hatırlatılmış. & - & - & - & - & - & - & - & - & 5 & 100 \\
\hline İki elin birlikte kullanımına yer verilmiştir. & - & - & - & - & - & - & - & - & 5 & 100 \\
\hline Bağlı - kesik çalma ile ilgili çalışmalar yapılmış. & - & - & 2 & 40 & 3 & 60 & - & - & - & - \\
\hline Çift ses çalışmalarına yer verilmiş. & - & - & - & - & 1 & 20 & 2 & 40 & 2 & 40 \\
\hline Üç ses - akor çalışmalarına yer verilmiş. & - & - & - & - & 1 & 20 & 2 & 40 & 2 & 40 \\
\hline Dizi çalışmaları ve parmak geçişlerine yer verilmiş. & 5 & 100 & & & & & & & & \\
\hline
\end{tabular}

Tablo 6'da uzmanların verdikleri cevaplar doğrultusunda Piano Party B kitabı boyunca doğru parmak el, bilek, dirsek duruşları ve piyano başında doğru oturuş, duruş ile ilgili bilgilere rastlanılmamaktadır. Ancak metotta doğru parmak numaraları belirli aralıklarla hatırlatılmıştır. İki el birlikte kullandırılmıştır. Bağlı-kesik çalma ile ilgili çalışmaların pek rastlanılmamıştır. Çift ses çalışmaları, üç ses-akor çalışmalarına yer verilmiştir. Ancak, dizi çalışmaları ve parmak geçişlerine yer verilmemiştir.

Tablo 7

Jane Smisor Bastien, Lisa Bastien ve Lori Bastien - Bastiens' - Invitation to Music: Piano Party B Metoduna Ait Müzikal ve Teorik Özellikler

\begin{tabular}{|c|c|c|c|c|c|c|c|c|c|c|}
\hline Müzikal ve Teorik Özellikler & 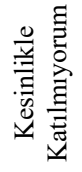 & $\partial^{\circ}$ & 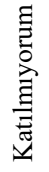 & $\Delta^{\circ}$ & 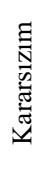 & $\partial^{\circ}$ & 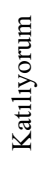 & $\AA^{\circ}$ & 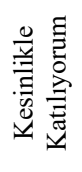 & $\partial^{\circ}$ \\
\hline İçindekiler veya öneriler kısmı ile öğretmen yönlendirilmiş. & - & - & - & - & - & - & 1 & 20 & 4 & 80 \\
\hline Temel müzik bilgilerine yer verilmiş. & - & - & - & - & - & - & 1 & 20 & 4 & 80 \\
\hline Hedef kitleye uygun nota ögretimi seçilmiş. & - & - & - & - & - & - & 1 & 20 & 4 & 80 \\
\hline Çeşitli bestecilerin eserlerine yer verilmiş. & 5 & 100 & - & - & - & - & - & - & - & - \\
\hline Besteci ve dönemler hakkında bilgiler verilmiş. & 5 & 100 & - & - & - & - & - & - & - & - \\
\hline Metot sistematik, sıralı ve planlı bir şekilde tasarlanmış. & - & - & - & - & - & - & 1 & 20 & 4 & 80 \\
\hline Öğretmen eşliğine yer verilmiş. & - & - & - & - & - & - & - & - & 5 & 100 \\
\hline Dört el çalışmalarına yer verilmiş. & 5 & 100 & - & - & - & - & - & - & - & - \\
\hline Doğaçlama çalışmalara yer verilmiş. & 2 & 40 & - & - & - & - & 1 & 20 & 2 & 40 \\
\hline Nota isimleri öğretilmiş. & - & - & - & - & - & - & - & - & 5 & 100 \\
\hline $\begin{array}{l}\text { Öğretilen notalar, anahtarlar, suslar, nüans terimleri, hız terimleri vb. } \\
\text { müzik bilgileri boyama, çizim gibi etkinliklerle pekiştirilmiş. }\end{array}$ & - & - & - & - & - & - & - & - & 5 & 100 \\
\hline Metodun sonunda öğrenciye sertifika verilmiş. & - & - & - & - & - & - & - & - & 5 & 100 \\
\hline Metotla birlikte $C D$ eki verilmiş. & 5 & 100 & - & - & - & - & - & - & - & - \\
\hline Metotla paralel çalıșma - ödev kitabı tasarlanmıș. & - & - & - & - & - & - & - & - & 5 & 100 \\
\hline
\end{tabular}

Tablo 7'de uzmanların verdikleri cevaplar doğrultusunda Piano Party B kitabının müzikal ve teorik özelliklerinin hedef kitleye çoğunlukla uyumlu olduğu görülmektedir. Kitapta içindekiler veya öneriler kısmı ile öğretmene yönlendirme yapılmıştır. Temel müzik bilgilerine yer verilmiştir ve hedef kitleye uygun nota öğretimi seçilmiştir. Metotta çeşitli bestecilerin eserlerine, besteci ve dönemler ile ilgili bilgilere yer verilmemiştir. Metot sistematik, sıralı ve planlı bir şekilde tasarlanmıştır. Öğretmen eşliklerine çeşitli parçalarda yer verilmiştir. Dört el çalışmalarına yer verilmemiştir. Doğaçlama çalışmalarına yer verilmiş ve nota isimleri öğretilmiştir. Az da olsa öğretilen notalar, anahtarlar, suslar, nüans terimleri, hız terimleri, vb. müzik bilgileri boyama ve çizim gibi etkinliklerle pekiştirilmiştir. Metodun sonunda öğrenciye bir sertifika verilmesi planlanmıştır. Metotla paralel çalışma-ödev kitabı tasarlanmıştır. Metotla birlikte CD eki verilmemiştir. Günümüz teknoloji çağında çocuğun evde CD veya web tabanlı bir uygulama yoluyla dinleme, çalma gibi pekiştirme çalışmaları yapması 
beklenmektedir. Bu metotta $\mathrm{CD}$ eki veya web tabanlı bir uygulama olmaması büyük bir eksiklik olarak göze çarpmaktadır.

\section{Tablo 8}

Jane Smisor Bastien, Lisa Bastien ve Lori Bastien - Bastiens' - Invitation to Music: Piano Party B Metoduna Ait Gelişimsel Özellikler

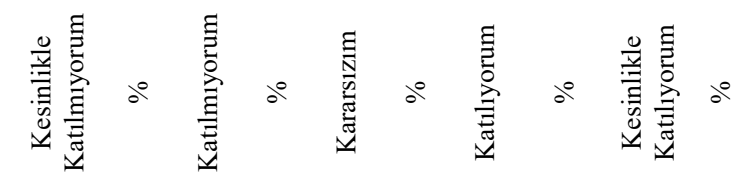

\begin{tabular}{|c|c|c|c|c|c|c|c|c|c|c|}
\hline \multicolumn{11}{|l|}{ Fiziksel Gelişim Özellikleri } \\
\hline Çocuğun piyano başında oturuşu ile ilgili kas, iskelet sağlığını & & & & & & & & & & \\
\hline $\begin{array}{l}\text { koruyucu uyarılar yapılmış ve ayağın altına tabure koyulması } \\
\text { sağlanmıştır. }\end{array}$ & 4 & 80 & 1 & 20 & - & - & - & - & - & - \\
\hline $\begin{array}{l}\text { Çocukların ellerini yumruk yaptırarak tuşlar üzerinde etkinlikler } \\
\text { yapılmıştır. }\end{array}$ & 2 & 40 & 1 & 20 & 2 & 40 & - & - & - & - \\
\hline $\begin{array}{l}\text { Çocukların daha güçlü olan } 1 \text { ve } 2 \text { numaraları parmaklarını kullandığı } \\
\text { etkinliklere daha fazla yer verilmiștir. }\end{array}$ & - & - & - & - & - & - & - & - & 5 & 100 \\
\hline $\begin{array}{l}\text { Çocukların daha zayıf olan } 4 \text { ve } 5 \text { numaraları parmaklarının kullanımı } \\
\text { ilerleyen etkinliklerde verilmiştir. }\end{array}$ & - & - & - & - & - & - & - & - & 5 & 100 \\
\hline $\begin{array}{l}\text { Çocukların görme becerilerine uygun olarak küçük ve ayrıntılı } \\
\text { figürlerden kaçılmış, büyük figürlere yer verilmiş. }\end{array}$ & - & - & - & - & - & - & - & - & 5 & 100 \\
\hline $\begin{array}{l}\text { Renk seçimi ve tonlamasında karmaşık olmayan bir yaklaşım } \\
\text { izlenmiştir. }\end{array}$ & - & - & - & - & - & - & 1 & 20 & 4 & 80 \\
\hline \multicolumn{11}{|l|}{ Bilişsel Gelişim Özellikleri } \\
\hline Piyano ile arkadaş olmaya yönelik temalar işlenmiştir. & - & - & - & - & 1 & 20 & - & - & 4 & 80 \\
\hline Dil gelişimine fayda sağlayacak çalışmalara yer verilmiştir. & - & - & - & - & - & - & - & - & 5 & 100 \\
\hline Dizeksiz nota eğitimi ile başlamıştır. & - & - & - & - & - & - & - & - & 5 & 100 \\
\hline Sade ve dikkat dağıtmayan sayfa planlamaları yapılmıştır. & - & - & - & - & - & - & 1 & 20 & 4 & 80 \\
\hline Etkinliklere başlarken eski konulara yer verilmiştir. & - & - & 1 & 20 & - & - & 4 & 80 & - & - \\
\hline $\begin{array}{l}\text { Etkinlik sonlarında sonraki etkinliklere hazırlayıcı çalışmalar } \\
\text { yapılmıştır. }\end{array}$ & - & - & 1 & 20 & - & - & 4 & 80 & - & - \\
\hline $\begin{array}{l}\text { İşlenilen etkinlikler doğrultusunda evde çalışılmak üzere alıştırmalara } \\
\text { yer verilmiştir. }\end{array}$ & - & - & 1 & 20 & - & - & 4 & 80 & - & - \\
\hline Etkinliklerde müzik kavramları somutlaştırılmıştır. & 1 & 20 & 2 & 40 & - & - & 2 & 40 & - & - \\
\hline $\begin{array}{l}\text { Nota saplarının yerlerinin değişmesi, sağ ve sol el geçişleri, aynı } \\
\text { anlama gelen farklı işaretlerin kullanılması vb. konularda açıklamalar } \\
\text { yapılmıştır. }\end{array}$ & - & - & - & - & - & - & 1 & 20 & 4 & 80 \\
\hline $\begin{array}{l}\text { Okul öncesi eğitim ilkelerinden "basitten karmaşığa" ilkesine uygun } \\
\text { bir ilerleme ele alınmıştır. }\end{array}$ & - & - & - & - & 1 & 20 & 1 & 20 & 3 & 60 \\
\hline $\begin{array}{l}\text { Okul öncesi eğitim ilkelerinden "bilinenden bilinmeyene" ilkesine } \\
\text { uygun bir ilerleme ele alınmıştır. }\end{array}$ & - & - & - & - & - & - & 1 & 20 & 4 & 80 \\
\hline $\begin{array}{l}\text { Okul öncesi eğitim ilkelerinden "somuttan soyuta" ilkesine uygun bir } \\
\text { ilerleme ele alınmıştır. }\end{array}$ & - & - & - & - & - & - & 1 & 20 & 4 & 80 \\
\hline $\begin{array}{l}\text { Okul öncesi eğitim ilkelerinden "nesnellik ve açıklık" ilkesine uygun } \\
\text { bir ilerleme ele alınmıştır. }\end{array}$ & - & - & - & - & - & - & 1 & 20 & 4 & 80 \\
\hline \multicolumn{11}{|l|}{ Sosyal ve Duygusal Gelișim Özellikleri } \\
\hline $\begin{array}{l}\text { Çocuğu piyano başında sıkmadan, çocuğun canını acıtacak kadar } \\
\text { parmaklarını yormadan, onu mutlu edip eğlendirecek özelliklere } \\
\text { sahiptir. }\end{array}$ & - & - & - & - & - & - & 1 & 20 & 4 & 80 \\
\hline $\begin{array}{l}\text { Öğretmeniyle veya piyano dersi alan başka bir arkadaşıyla birlikte } \\
\text { çalma etkinliklerine yer verilmiştir. }\end{array}$ & - & - & 1 & 20 & - & - & - & - & 4 & 80 \\
\hline $\begin{array}{l}\text { Doğaçlama, birlikte çalma vb. etkinliklerle çocuğun girişkenliğini öne } \\
\text { çıkaracak çalışmalara yer verilmiştir. }\end{array}$ & - & - & - & - & - & - & - & - & 5 & 100 \\
\hline $\begin{array}{l}\text { Metot aileyi öğrenme sürecine dahil eder ve çocuğun evde düzenli } \\
\text { çalışmass ile ilgili aile denetimi istenmiştir. }\end{array}$ & 2 & 40 & 1 & 20 & 1 & 20 & 1 & 20 & - & - \\
\hline $\begin{array}{l}\text { Oyun gelişimi ve yaratıcılığı destekleyen çocuk merkezli etkinliklere } \\
\text { yer verilmiştir. }\end{array}$ & - & - & - & - & - & - & - & - & 5 & 100 \\
\hline
\end{tabular}

Tablo 8'de uzmanların verdikleri cevaplar doğrultusunda Piano Party B kitabının gelişimsel özelliklerinin hedef kitleye çoğunlukla uyumlu olduğu görülmektedir. Fiziksel gelişim özelliklerine bakıldığında kitapta; çocuğun piyano başında oturuşu ile ilgili kas, iskelet sağlığını koruyucu uyarılara ve ayağın altına tabure koyulması ile ilgili herhangi bir bilgilendirmeye rastlanmamıştır. Çocukların ellerini yumruk yaptırarak tuşlar üzerinde etkinlikler yaptırıldığı da görülmemektedir. Çocukların daha güçlü olan 1 ve 2 numaraları parmaklarını kullandığı etkinliklere daha fazla yer verilmiştir. Bu doğrultuda çocukların daha zayıf olan 4 ve 5 numaraları parmaklarının kullanımlarına da ilerleyen etkinliklerde verilmiştir. Çocukların görme becerilerine uygun olarak küçük ve ayrıntılı figürlerden kaçılmış ve büyük figürlere daha çok yer verilmiştir. Metot boyunca renk seçimi ve tonlamasında karmaşık olmayan bir yaklaşım izlendiği görülmüştür. Bilişsel gelişim özellikleri ele alındığında kitapta, piyano ile arkadaş olmaya yönelik temalar işlenmiştir. Dil gelişimine fayda sağlayacak 
çalışmalar görülmektedir. Metotta, bu yaş grubundaki çocuğun gelişimini olumlu yönde etkileyecek çalışmalar vardır. Dizeksiz nota eğitimine yer verildiği ve dikkat dağıtmayan sayfa planlamaları yapıldığı görülmektedir. Etkinlik başlarında eski konuların tekrarlarına, etkinlik sonlarında ise yeni konuya hazırlayıcı çalışmalara yer verilmiştir. Derslerde yapılan etkinlikler doğrultusunda evde çalışılmak üzere alıştırmalara yer verilmişstir. Etkinliklerde müzik kavramlarının somutlaştırılması konusuna uzmanların bir kısmı katılmış bir kısmı ise katılmamıştır. Müzik kavramlarının somutlaştırılarak anlatılması hedef yaş grubu için öğrenmeyi kolaylaştırmakta ve önemli görülmektedir. Nota saplarının yerlerinin değişmesi, sağ ve sol el geçişleri, aynı anlama gelen farklı işaretlerin kullanılması vb. konuların çoğunda açıklamalar yapılmıştır. Okul öncesi eğitim ilkelerinden "basitten karmaşı̆̆a", "bilinenden bilinmeyene", "somuttan soyuta", "nesnellik ve açıklık" ilkelerine uygun bir ilerleme ele alınmıştır. Sosyal ve duygusal gelişim özellikleri ele alındığında kitapta; çocuğu piyano başında sıkmadan, çocuğun canını acıtacak kadar parmaklarını yormadan, onu mutlu edip eğlendirecek özelliklere sahip bir ilerleme görülmektedir. Metotta öğretmeniyle veya piyano dersi alan başka bir arkadaşıyla birlikte çalma etkinliklerine, doğaçlama, birlikte çalma vb. etkinlikler bulunmaktadır. Bu etkinlikler doğrultusunda çocuğun girişkenliğini öne çıkaracak çalışmalar görülmektedir. Oyun gelişimi ve yaratıcılığ destekleyen çocuk merkezli etkinlikler metotta bulunmaktadır. Ancak metot aileyi öğrenme sürecine dahil etmez ve çocuğun evde düzenli çalışması ile ilgili aile denetimi istenmemiştir.

Tablo 9

Nancy Faber ve Randall Faber - My First Piano Adventure: Lesson Book A Metoduna Ait Görsel Özellikler

Görsel Özellikler

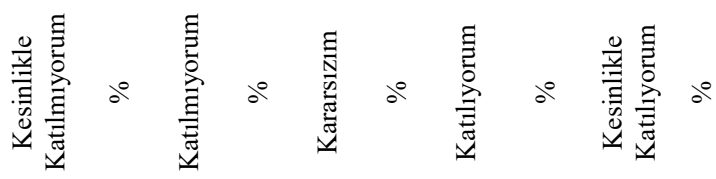

\begin{tabular}{|c|c|c|c|c|c|c|c|c|c|c|}
\hline Metodun diş kapağı güzel planlanmış. & - & - & - & - & 1 & 20 & 3 & 60 & 1 & 20 \\
\hline Metodun sayfa düzeni planlaması güzel yapılmış. & - & - & - & - & - & - & 4 & 80 & 1 & 20 \\
\hline $\begin{array}{l}\text { Nota, ölçü, dizek, sus, vb. bütün işaretlerin büyüklüğ̈̈ hedef kitleye } \\
\text { uygun planlanmış. }\end{array}$ & - & - & - & - & - & - & 2 & 40 & 3 & 60 \\
\hline Kullanılan resim ve fotoğraflar hedef kitleye uygun seçilmiş. & - & - & - & - & - & - & 2 & 40 & 3 & 60 \\
\hline $\begin{array}{l}\text { Kullanılan resim ve fotoğraflar renk, boyut, vb. kıstaslar açısından ilgi } \\
\text { çekici. }\end{array}$ & - & - & - & - & - & - & 2 & 40 & 3 & 60 \\
\hline $\begin{array}{l}\text { Kullanılan yazı karakterleri, punto gibi tipografik özellikler hedef } \\
\text { kitleye uygun seçilmiș. }\end{array}$ & - & - & - & - & - & - & 1 & 20 & 4 & 80 \\
\hline
\end{tabular}

Tablo 9'da görüleceği üzere uzmanlar görsel özelliklerdeki kriterlere katıllyorum ve kesinlikle katılıyorum cevaplarını vermiştir. Buna göre, Lesson Book A kitabının bütün görsel özellikleri hedef kitleye uymaktadır. Metodun dış kapağı ve sayfa düzeni göze hoş gelmektedir. Nota, ölçü, dizek, sus, vb. bütün işaretlerin büyüklükleri çocuklara uygundur. Kullanılan resim ve fotoğraflar çocukların ilgisini çekecek şekildedir. Bu doğrultuda kullanılan resim ve fotoğraflar renk, boyut, vb. kıstaslar açısından da ilgi çekicidir. Kullanılan yazı karakterleri, punto gibi tipografik özellikler de hedef kitleye uygundur.

Tablo 10

Nancy Faber ve Randall Faber - My First Piano Adventure: Lesson Book A Metoduna Ait Teknik Özellikler

\begin{tabular}{|c|c|c|c|c|c|c|c|c|c|c|}
\hline Teknik Özellikler & 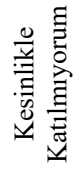 & $\partial^{\circ}$ & 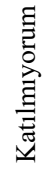 & $\partial^{0}$ & 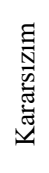 & $\partial^{\circ}$ & 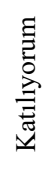 & $a^{0}$ & 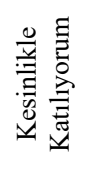 & $\partial^{0}$ \\
\hline Doğru parmak, el, bilek, dirsek duruşları ile ilgili bilgiler verilmiş. & - & - & - & - & - & - & - & - & 5 & 100 \\
\hline Piyano başında doğru oturuş ve duruş ile ilgili bilgiler verilmiş. & - & - & - & - & - & - & - & - & 5 & 100 \\
\hline Doğru parmak numaraları belirli aralıklarla hatırlatılmış. & - & - & - & - & - & - & - & - & 5 & 100 \\
\hline İki elin birlikte kullanımına yer verilmiştir. & - & - & - & - & - & - & - & - & 5 & 100 \\
\hline Bağlı - kesik çalma ile ilgili çalışmalar yapılmış. & 2 & 40 & 1 & 20 & 1 & 20 & - & - & 1 & 20 \\
\hline Çift ses çalışmalarına yer verilmiş. & - & - & - & - & 3 & 60 & 2 & 40 & - & - \\
\hline Üç ses - akor çalışmalarına yer verilmiş. & 1 & 20 & 2 & 40 & 1 & 20 & 1 & 20 & - & - \\
\hline Dizi çalışmaları ve parmak geçişlerine yer verilmiş. & - & - & - & - & - & - & - & - & 5 & 100 \\
\hline
\end{tabular}

Tablo 10'da uzmanların verdikleri cevaplar doğrultusunda Lesson Book A kitabının teknik özelliklerinin hedef kitleye uygun planlandığı görülmektedir. Doğru parmak el, bilek, dirsek duruşları ve piyano başında doğru oturuş, duruş ile ilgili bilgiler fotoğraflarla desteklenmiştir. Doğru parmak numaraları belli aralıklarla hatırlatılmıştır. Bu yaş grubu için parmak numaralarını tekrar tekrar hatırlatmak önemlidir. İki elin birlikte kullanılması ve çift ses çalışmaları metotta bulunmaktadır. Metotta bağlı-kesik çalma ile ilgili çalışmalar, üç ses-akor çalışmaları, dizi çalışmaları ve parmak geçişleri ile ilgili herhangi bir alıştırma göze çarpmamaktadır. 
Tablo 11

Nancy Faber ve Randall Faber - My First Piano Adventure: Lesson Book A Metoduna Ait Müzikal ve Teorik Özellikler

Müzikal ve Teorik Özellikler

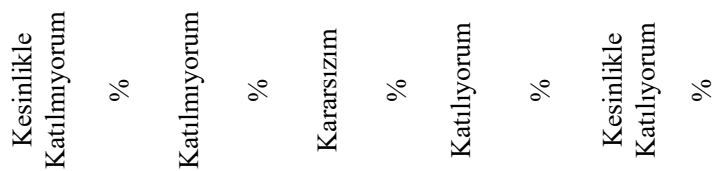

İçindekiler veya öneriler kısmı ile öğretmen yönlendirilmiş.

Temel müzik bilgilerine yer verilmiş.

Hedef kitleye uygun nota öğretimi seçilmiş.

Çeşitli bestecilerin eserlerine yer verilmiş.

Besteci ve dönemler hakkında bilgiler verilmiș.

Metot sistematik, sıralı ve planlı bir şekilde tasarlanmış.

Öğretmen eşliğine yer verilmiş.

Dört el çalışmalarına yer verilmiş.

Doğaçlama çalışmalara yer verilmiş.

Nota isimleri öğretilmiș.

Öğretilen notalar, anahtarlar, suslar, nüans terimleri, hız terimleri vb.

müzik bilgileri boyama, çizim gibi etkinliklerle pekiştirilmiş.

Metodun sonunda öğrenciye sertifika verilmiş.

Metotla birlikte CD eki verilmiş.

Metotla paralel çalıșma - ödev kitabı tasarlanmıș.

$\begin{array}{cccccccccc}- & - & - & - & - & - & - & - & 5 & 100 \\ - & - & - & - & - & - & - & - & 5 & 100 \\ - & - & - & - & - & - & - & - & 5 & 100 \\ 5 & 100 & - & - & - & - & - & - & - & - \\ 5 & 100 & - & - & - & - & - & - & - & - \\ - & - & - & - & - & - & 1 & 20 & 4 & 80 \\ - & - & - & - & - & - & - & - & 5 & 100 \\ 5 & 100 & - & - & - & - & - & - & - & - \\ - & - & - & - & - & - & 2 & 40 & 3 & 60 \\ - & - & - & - & - & - & - & - & 5 & 100 \\ 5 & 100 & - & - & - & - & - & - & - & - \\ - & - & - & - & - & - & - & - & 5 & 100 \\ - & - & - & - & - & - & - & - & 5 & 100 \\ - & - & - & - & - & - & 1 & 20 & 4 & 80\end{array}$

Tablo 11'de uzmanların cevapları doğrultusunda Lesson Book A kitabının müzikal ve teorik özelliklerinin hedef kitleye çoğunlukla uyumlu olduğu görülmektedir. Kitapta içindekiler veya öneriler kısmı ile öğretmen yönlendirilmiştir. Temel müzik bilgileri öğretilmiştir. Hedef kitleye uygun nota öğretimi seçilmiştir. Dizeksiz nota öğretimi kullanılmıştır. Metotta çeşitli bestecilerin eserlerine, besteci ve dönemler ile ilgili bilgilere yer verilmemiştir. Metot sistematik, sıralı ve planlı bir şekilde tasarlanmıştır. Öğretmen eşliklerine bazı parçalarda rastlanılmaktadır. Uzmanlar, birlikte müzik yapmak adına öğretmen eşliğinin ne kadar önemli olduğunu vurgulamıştır. Dört el çalışmalarına yer verilmemiş̧ir. Doğaçlama çalışmalarına yer verilmiş ve nota isimleri öğretilmiştir. Ancak öğretilen notalar, anahtarlar, suslar, nüans terimleri, hız terimleri, vb. müzik bilgileri boyama ve çizim gibi etkinliklerle pekiştirilmemiştir. Bu yaş grubu boyama ve çizim yapmayı sevdiği için bu gibi etkinliklere yer verilmesi beklenirdi. Metodun sonunda öğrenciye bir sertifika verilecektir. Metotla paralel çalışma - ödev kitabı tasarlanmıştır. Metotla paralel ilerleyen destekleyici kaynaklar oldukça değerlidir. Metotla birlikte verilen $\mathrm{CD}$ eki günümüz teknolojisi de göz önünde bulundurulduğunda doğru bir planlama olmuştur ancak web tabanlı bir uygulamanın olması daha faydalı olacaktır. Evde çocuk CD'den hem şarkıları dinleyebilir, hem söyleyebilir, hem de piyanoda çalabilir.

Tablo 12

Nancy Faber ve Randall Faber - My First Piano Adventure: Lesson Book A Metoduna Ait Gelişimsel Özellikler

Gelişimsel Özellikler

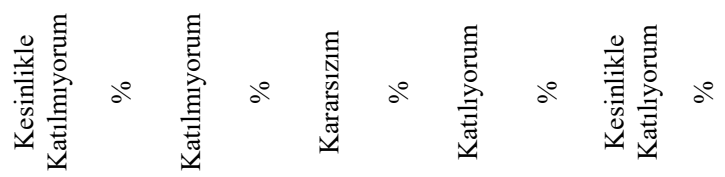

\begin{tabular}{|c|c|c|c|c|c|c|c|c|c|c|}
\hline \multicolumn{11}{|l|}{ Fiziksel Gelișim Özellikleri } \\
\hline Çocuğun piyano başında oturuşu ile ilgili kas, iskelet sağlı̆ıını & & & & & & & & & & \\
\hline $\begin{array}{l}\text { koruyucu uyarılar yapılmış ve ayağın altına tabure koyulması } \\
\text { sağlanmıştır. }\end{array}$ & 1 & 20 & - & - & - & - & 4 & 80 & - & - \\
\hline $\begin{array}{l}\text { Çocukların ellerini yumruk yaptırarak tuşlar üzerinde etkinlikler } \\
\text { yapılmıştır. }\end{array}$ & - & - & - & - & - & - & 1 & 20 & 4 & 80 \\
\hline $\begin{array}{l}\text { Çocukların daha güçlü olan } 1 \text { ve } 2 \text { numaraları parmaklarını kullandığı } \\
\text { etkinliklere daha fazla yer verilmiştir. }\end{array}$ & - & - & - & - & - & - & - & - & 5 & 100 \\
\hline $\begin{array}{l}\text { Çocukların daha zayıf olan } 4 \text { ve } 5 \text { numaraları parmaklarının kullanımı } \\
\text { ilerleyen etkinliklerde verilmiştir. }\end{array}$ & - & - & - & - & - & - & - & - & 5 & 100 \\
\hline $\begin{array}{l}\text { Çocukların görme becerilerine uygun olarak küçük ve ayrıntılı } \\
\text { figürlerden kaçılmış, büyük figürlere yer verilmiş. }\end{array}$ & - & - & - & - & - & - & - & - & 5 & 100 \\
\hline $\begin{array}{l}\text { Renk seçimi ve tonlamasında karmaşı olmayan bir yaklaşım } \\
\text { izlenmiştir. }\end{array}$ & - & - & - & - & - & - & - & - & 5 & 100 \\
\hline \multicolumn{11}{|l|}{ Bilişsel Gelişim Özellikleri } \\
\hline Piyano ile arkadaş olmaya yönelik temalar işlenmiştir. & - & - & - & - & - & - & - & - & 5 & 100 \\
\hline Dil gelişimine fayda sağlayacak çalışmalara yer verilmiştir. & - & - & - & - & - & - & - & - & 5 & 100 \\
\hline Dizeksiz nota eğitimi ile başlamıştır. & - & - & - & - & - & - & - & - & 5 & 100 \\
\hline Sade ve dikkat dağıtmayan sayfa planlamaları yapılmıştır. & - & - & - & - & 2 & 40 & 2 & 40 & 1 & 20 \\
\hline Etkinliklere başlarken eski konulara yer verilmiştir. & - & - & 1 & 20 & - & - & 2 & 40 & 2 & 80 \\
\hline
\end{tabular}


Tablo 12'nin devamı

\begin{tabular}{|c|c|c|c|c|c|c|c|c|c|c|}
\hline Bilişsel Gelişim Özellikleri & 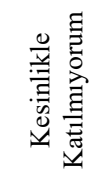 & $\partial^{\circ}$ & 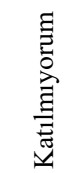 & $0^{\circ}$ & 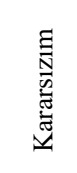 & $\partial^{\circ}$ & 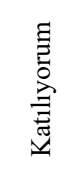 & $\partial^{\circ}$ & 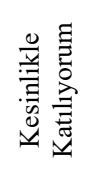 & $\therefore$ \\
\hline $\begin{array}{l}\text { Etkinlik sonlarında sonraki etkinliklere hazırlayıcı çalışmalar } \\
\text { yapılmıştır. }\end{array}$ & - & - & 1 & 20 & - & - & 2 & 40 & 2 & 80 \\
\hline $\begin{array}{l}\text { İşlenilen etkinlikler doğrultusunda evde çalışılmak üzere alıştırmalara } \\
\text { yer verilmiştir. }\end{array}$ & - & - & - & - & 1 & 20 & 4 & 80 & - & - \\
\hline Etkinliklerde müzik kavramları somutlaştırılmıştır. & - & - & - & - & - & - & 1 & 20 & 4 & 80 \\
\hline $\begin{array}{l}\text { Nota saplarının yerlerinin değişmesi, sağ ve sol el geçişleri, aynı } \\
\text { anlama gelen farklı işaretlerin kullanılması vb. konularda açıklamalar } \\
\text { yapılmıştır. }\end{array}$ & - & - & - & - & - & - & 3 & 60 & 2 & 40 \\
\hline $\begin{array}{l}\text { Okul öncesi eğitim ilkelerinden "basitten karmaşığa" ilkesine uygun } \\
\text { bir ilerleme ele alınmıștır. }\end{array}$ & - & - & - & - & - & - & 1 & 20 & 4 & 80 \\
\hline $\begin{array}{l}\text { Okul öncesi eğitim ilkelerinden "bilinenden bilinmeyene" ilkesine } \\
\text { uygun bir ilerleme ele alınmıştır. }\end{array}$ & - & - & - & - & - & - & 1 & 20 & 4 & 80 \\
\hline $\begin{array}{l}\text { Okul öncesi eğitim ilkelerinden "somuttan soyuta" ilkesine uygun bir } \\
\text { ilerleme ele alınmıştır. }\end{array}$ & - & - & - & - & - & - & 1 & 20 & 4 & 80 \\
\hline $\begin{array}{l}\text { Okul öncesi eğitim ilkelerinden "nesnellik ve açıklık" ilkesine uygun } \\
\text { bir ilerleme ele alınmıştır. }\end{array}$ & - & - & - & - & - & - & 1 & 20 & 4 & 80 \\
\hline \multicolumn{11}{|l|}{ Sosyal ve Duygusal Gelişim Özellikleri } \\
\hline $\begin{array}{l}\text { Çocuğu piyano başında sıkmadan, çocuğun canını acıtacak kadar } \\
\text { parmaklarını yormadan, onu mutlu edip eğlendirecek özelliklere } \\
\text { sahiptir. }\end{array}$ & - & - & 1 & 20 & - & - & - & - & 4 & 80 \\
\hline $\begin{array}{l}\text { Öğretmeniyle veya piyano dersi alan başka bir arkadaşıyla birlikte } \\
\text { çalma etkinliklerine yer verilmiştir. }\end{array}$ & - & - & - & - & - & - & - & - & 5 & 100 \\
\hline $\begin{array}{l}\text { Doğaçlama, birlikte çalma vb. etkinliklerle çocuğun girişkenliğini öne } \\
\text { çıkaracak çalışmalara yer verilmiştir. }\end{array}$ & - & - & - & - & - & - & - & - & 5 & 100 \\
\hline $\begin{array}{l}\text { Metot aileyi ögrrenme sürecine dahil eder ve çocuğun evde düzenli } \\
\text { çalıșması ile ilgili aile denetimi istenmiştir. }\end{array}$ & 5 & 100 & - & - & - & - & - & - & - & - \\
\hline $\begin{array}{l}\text { Oyun gelişimi ve yaratıcılığı destekleyen çocuk merkezli etkinliklere } \\
\text { yer verilmiştir. }\end{array}$ & - & - & - & - & - & - & 1 & 20 & 4 & 80 \\
\hline
\end{tabular}

Tablo 12'ye bakıldığında uzmanların verdikleri cevaplar doğrultusunda Lesson Book A kitabının gelişimsel özelliklerinin hedef kitleye uyumlu olduğu görülmektedir. Fiziksel gelişim özelliklerine bakıldığında kitapta; çocuğun piyano başında oturuşu ile ilgili kas, iskelet sağlığını koruyucu uyarılara rastlanılmakta ancak ayağın altına tabure koyulması ile ilgili herhangi bir bilgilendirmeye rastlanmamıştır. Çocukların ellerini yumruk yaptırarak tuşlar üzerinde etkinlikler yaptırılmıştır. Çocukların daha güçlü olan 1 ve 2 numaraları parmaklarını kullandığ 1 etkinliklere daha fazla yer verilmiştir. Bununla birlikte çocukların daha zayıf olan 4 ve 5 numaraları parmaklarının kullanımlarına ilerleyen etkinliklerde verildiği görülmektedir. Çocukların görme becerilerine uygun olarak küçük ve ayrıntılı figürlerden kaçılmış ve büyük figürlere yer verilmiştir. Renk seçimi ve tonlamasında karmaşık olmayan bir yaklaşım izlenmiştir. Bu gibi özellikler hedef yaş grubu için önemlidir. Bilişsel gelişim özellikleri ele alındığında kitapta; piyano ile arkadaş olmaya yönelik temaların işlendiği, dil gelişimine fayda sağlayacak çalışmalara yer verildiği gözlemlenmiştir. Dizeksiz nota eğitimi ile başlayıp dizekli nota eğitimi ile devam edilmiştir. Bu yaş grubu için güzel bir planlama olarak göze çarpmaktadır. Dikkat dağıtmayan sayfa planlamaları yapıldığı görülmektedir. Etkinlik başlarında eski konuların tekrarlarına, etkinlik sonlarında da yeni konuya hazırlayıcı çalışmalara yer verilmiştir. Metot boyunca işlenilen etkinlikler doğrultusunda evde çalışılmak üzere alıştırmalara rastlanılmaktadır. Etkinliklerde müzik kavramları somutlaştırılmıştır. Nota saplarının yerlerinin değişmesi, sağ ve sol el geçişleri, aynı anlama gelen farklı işaretlerin kullanılması vb. konuların bazılarında açıklamalar yapılmış bazılarında yapılmamıştır. Okul öncesi eğitim ilkelerinden "basitten karmaşığa", "bilinenden bilinmeyene", "somuttan soyuta", "nesnellik ve açıklık" ilkelerine uygun bir ilerleme söz konusudur. Sosyal ve duygusal gelişim özellikleri ele alındığında kitapta; çocuğu piyano başında sıkmadan, çocuğun canını acıtacak kadar parmaklarını yormadan, onu mutlu edip eğlendirecek özelliklere sahip bir ilerleme gözlemlenmektedir. Metotta öğretmeniyle veya piyano dersi alan başka bir arkadaşıyla birlikte çalma etkinliklerine yer verilmiştir ki bu çok önemlidir. Doğaçlama, birlikte çalma vb. etkinliklerle çocuğun girişkenliğini öne çıkaracak çalışmalar göze çarpmaktadır. Oyun gelişimi ve yaratıcılığ destekleyen çocuk merkezli etkinliklere yer verilmiştir. Ancak metot aileyi öğrenme sürecine dahil etmez ve çocuğun evde düzenli çalışması ile ilgili aile denetimi istenmemiştir. 
Tablo 13

Nancy Faber ve Randall Faber - My First Piano Adventure: Lesson Book B Metoduna Ait Görsel Özellikler

Görsel Özellikler

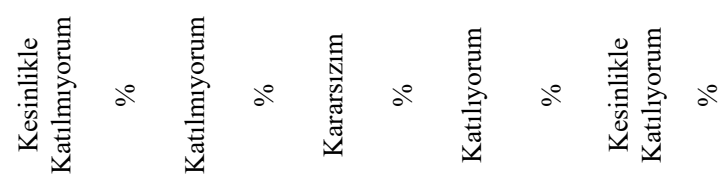

\begin{tabular}{|c|c|c|c|c|c|c|c|c|c|c|}
\hline Metodun diş kapağı güzel planlanmıș. & - & - & - & - & 2 & $\overline{40}$ & 2 & 40 & 1 & 20 \\
\hline Metodun sayfa düzeni planlaması güzel yapılmış. & - & - & - & - & - & - & 4 & 80 & 1 & 20 \\
\hline $\begin{array}{l}\text { Nota, ölçü, dizek, sus, vb. bütün işaretlerin büyüklüğü hedef kitleye } \\
\text { uygun planlanmış. }\end{array}$ & - & - & - & - & - & - & 2 & 40 & 3 & 60 \\
\hline Kullanılan resim ve fotoğraflar hedef kitleye uygun seçilmiş. & - & - & - & - & - & - & 2 & 40 & 3 & 60 \\
\hline $\begin{array}{l}\text { Kullanılan resim ve fotoğraflar renk, boyut, vb. kıstaslar açısından ilgi } \\
\text { çekici. }\end{array}$ & - & - & - & - & - & - & 2 & 40 & 3 & 60 \\
\hline $\begin{array}{l}\text { Kullanılan yazı karakterleri, punto gibi tipografik özellikler hedef } \\
\text { kitleye uygun seçilmiş. }\end{array}$ & - & - & - & - & - & - & 1 & 20 & 4 & 80 \\
\hline
\end{tabular}

Tablo 13'te uzmanlara göre Lesson Book B kitabının bütün görsel özelliklerinin hedef kitleye uyumlu olduğu görülmektedir. Metodun diş kapağı konusunda kararsız kalan uzmanlar olsa da dış kapak ve sayfa düzeni planlaması göze hoş gelmektedir. Nota, ölçü, dizek, sus, vb. bütün işaretlerin büyüklükleri çocukların okuyabileceği şekildedir. Kullanılan resim ve fotoğraflar hedef kitleye uygundur. Kullanılan resim ve fotoğraflar renk, boyut, vb. kıstaslar açısından çocukların ilgisini çekecek şekildedir. Kullanılan yazı karakterleri, punto gibi tipografik özellikler de hedef yaş grubuna uygundur.

\section{Tablo 14}

Nancy Faber ve Randall Faber - My First Piano Adventure: Lesson Book B Metoduna Ait Teknik Özellikler

Teknik Özellikler

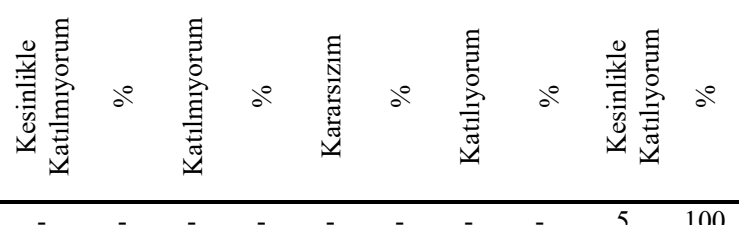

\begin{tabular}{lllllllllll}
\hline Doğru parmak, el, bilek, dirsek duruşları ile ilgili bilgiler verilmiş. & - & - & - & - & - & - & - & - & 5 & 100 \\
Piyano başında doğru oturuş ve duruş ile ilgili bilgiler verilmiş. & - & - & - & - & - & - & - & - & 5 & 100 \\
Doğru parmak numaraları belirli aralıklarla hatırlatılmış. & - & - & - & - & - & - & - & - & 5 & 100 \\
İki elin birlikte kullanımına yer verilmiştir. & - & - & - & - & - & - & - & - & 5 & 100 \\
Bağlı - kesik çalma ile ilgili çalışmalar yapılmış. & 2 & 40 & 1 & 20 & 1 & 20 & - & - & 1 & 20 \\
Çift ses çalışmalarına yer verilmiş. & - & - & - & - & - & - & 1 & 20 & 4 & 80 \\
U̦ç ses - akor çalışmalarına yer verilmiş. & - & - & - & - & 2 & 40 & - & - & 3 & 60 \\
Dizi çalışmaları ve parmak geçişlerine yer verilmiş. & 5 & 100 & - & - & - & - & - & - & - & - \\
\hline
\end{tabular}

Tablo 14'te uzmanların verdikleri cevaplar doğrultusunda Lesson Book B kitabının teknik özelliklerinin hedef kitleye çoğunlukla uyumlu olduğu görülmektedir. Doğru parmak el, bilek, dirsek duruşları ve piyano başında doğru oturuş, duruş ile ilgili bilgiler fotoğraflarla desteklenmiş ve bu konuda açıklamalar yapılmıştır. Doğru parmak numaraları belirli aralıklarla hatırlatılmıştır. Bu yaş grubunda parmak numaralarının hatırlatılması önemlidir. İki elin birlikte kullanılması, çift ses çalışmaları, üç ses - akor çalışmaları metotta yer almıştır. Metotta bağlı-kesik çalma ile ilgili çalışmalar bulunmamaktadır. Dizi çalışmaları ve parmak geçişleri ile ilgili herhangi bir alıştırma yoktur.

Tablo 15

Nancy Faber ve Randall Faber - My First Piano Adventure: Lesson Book B Metoduna Ait Müzikal ve Teorik

\begin{tabular}{|c|c|c|c|c|c|c|c|c|c|c|}
\hline Müzikal ve Teorik Özellikler & 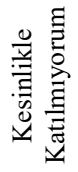 & $a^{\circ}$ & 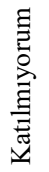 & $\partial^{\circ}$ & 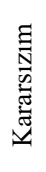 & $0^{\circ}$ & 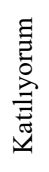 & $\partial^{\circ}$ & 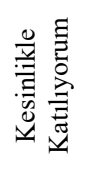 & $a^{\circ}$ \\
\hline İçindekiler veya öneriler kısmı ile öğretmen yönlendirilmiş. & - & - & - & - & - & - & - & - & 5 & 100 \\
\hline Temel müzik bilgilerine yer verilmiş. & - & - & - & - & - & - & - & - & 5 & 100 \\
\hline Hedef kitleye uygun nota öğretimi seçilmiş. & - & - & - & - & - & - & - & - & 5 & 100 \\
\hline Çeşitli bestecilerin eserlerine yer verilmiş. & 5 & 100 & - & - & - & - & - & - & - & - \\
\hline Besteci ve dönemler hakkında bilgiler verilmiș. & 4 & 80 & - & - & 1 & 20 & - & - & - & - \\
\hline Metot sistematik, sıralı ve planlı bir şekilde tasarlanmış. & - & - & - & - & - & - & - & - & 5 & 100 \\
\hline Öğretmen eşliğine yer verilmiș. & - & - & - & - & - & - & - & - & 5 & 100 \\
\hline Dört el çalıșmalarına yer verilmiş. & 5 & 100 & - & - & - & - & - & - & - & - \\
\hline
\end{tabular}
Özellikler 
Tablo 15'in devamı

\begin{tabular}{|c|c|c|c|c|c|c|c|c|c|c|}
\hline Müzikal ve Teorik Özellikler & 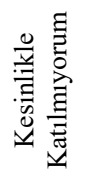 & $0^{\circ}$ & 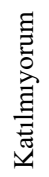 & $a^{\circ}$ & 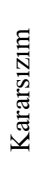 & $a^{\circ}$ & 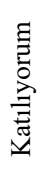 & $\partial^{\circ}$ & 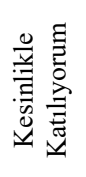 & $a^{\circ}$ \\
\hline Doğaçlama çalışmalara yer verilmiş. & 1 & 20 & 1 & 20 & - & - & - & - & 3 & 60 \\
\hline Nota isimleri öğretilmiş. & 1 & 20 & - & - & - & - & - & - & 4 & 80 \\
\hline $\begin{array}{l}\text { Öğretilen notalar, anahtarlar, suslar, nüans terimleri, hız terimleri vb. } \\
\text { müzik bilgileri boyama, çizim gibi etkinliklerle pekiştirilmiş. }\end{array}$ & 4 & 80 & - & - & - & - & - & - & 1 & 20 \\
\hline Metodun sonunda öğrenciye sertifika verilmiş. & - & - & - & - & - & - & - & - & 5 & 100 \\
\hline Metotla birlikte CD eki verilmiş. & - & - & - & - & - & - & - & - & 5 & 100 \\
\hline Metotla paralel çalışma - ödev kitabı tasarlanmış. & - & - & - & - & - & - & 1 & 20 & 4 & 80 \\
\hline
\end{tabular}

Tablo 15’te görüldüğü üzere Lesson Book B kitabında içindekiler veya öneriler kısmı ile öğretmene yönlendirme yapılmıştır. Temel müzik bilgilerine yer verilmiştir ve hedef kitleye uygun nota öğretimi seçilmiştir. Hedef kitleye uygun nota öğretimi seçilmiştir. Dizeksiz nota öğretimi yerini dizekli nota öğretimine bırakmıştır. Metotta çeşitli bestecilerin eserlerine, besteci ve dönemler ile ilgili bilgilere yer verilmemiştir. Metot sistematik, sıralı ve planlı bir şekilde tasarlanmıştır. Öğretmen eşliklerine yer verilmiştir. Birlikte müzik yapmak adına öğretmen eşlikleri önemlidir. Dört el çalışmalarına yer verilmemiştir. Doğaçlama çalışmalara yer verilmiş, nota isimleri öğretilmiştir ancak öğretilen notalar, anahtarlar, suslar, nüans terimleri, hız terimleri, vb. müzik bilgileri boyama ve çizim gibi etkinliklerle pekiştirilmemiştir. Metodun sonunda öğrenciye bir sertifika verilecektir. Metotla paralel çalışma - ödev kitabı tasarlanmıştır. Metotla paralel ilerleyen yardımcı kitaplar oldukça önemlidir. Metotla birlikte verilen CD eki günümüz teknolojisi de göz önünde bulundurulduğunda doğru bir planlama olmuştur ancak web tabanlı bir uygulamanın olması daha faydalı olacaktır. Evde çocuk CD'den hem şarkıları dinleyebilir, hem söyleyebilir, hem de piyanoda çalabilir.

Tablo 16

Nancy Faber ve Randall Faber - My First Piano Adventure: Lesson Book B Metoduna Ait Gelişimsel Özellikler

Gelișimsel Özellikler

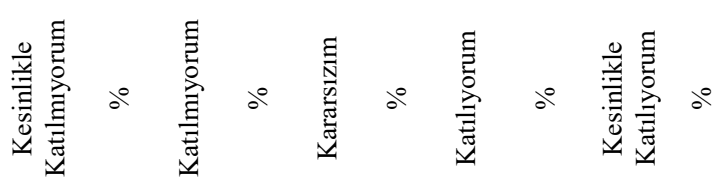

\section{Fiziksel Gelişim Özellikleri}

Çocuğun piyano başında oturuşu ile ilgili kas, iskelet sağlığını koruyucu uyarılar yapılmış ve ayağın altına tabure koyulması sağlanmıştır.

Çocukların ellerini yumruk yaptırarak tuşlar üzerinde etkinlikler yapılmıştır

Çocukların daha güçlü olan 1 ve 2 numaraları parmaklarını kullandığı etkinliklere daha fazla yer verilmiştir.

Çocukların daha zayıf olan 4 ve 5 numaraları parmaklarının kullanımı ilerleyen etkinliklerde verilmiştir.

Çocukların görme becerilerine uygun olarak küçük ve ayrıntılı figürlerden kaçılmış, büyük figürlere yer verilmiş.

Renk seçimi ve tonlamasında karmaşık olmayan bir yaklaşım izlenmiştir.

$\begin{array}{llllllllll}- & - & - & - & 1 & 20 & 4 & 80 & - & - \\ 1 & 20 & 1 & 20 & 2 & 40 & - & - & 1 & 20 \\ - & - & - & - & - & - & - & - & 5 & 100 \\ - & - & - & - & - & - & - & - & 5 & 100 \\ - & - & - & - & - & - & - & - & 5 & 100 \\ - & - & - & - & - & - & 1 & 20 & 4 & 80\end{array}$

Bilissel Gelisim Özellikleri

Piyano ile arkadaş olmaya yönelik temalar işlenmiștir.

Dil gelişimine fayda sağlayacak çalışmalara yer verilmiştir.

Dizeksiz nota eğitimi ile başlamıştır.

Sade ve dikkat dağıtmayan sayfa planlamaları yapılmıştır.

Etkinliklere başlarken eski konulara yer verilmiştir.

Etkinlik sonlarında sonraki etkinliklere hazırlayıcı çalışmalar

yapılmıştır.

İşlenilen etkinlikler doğrultusunda evde çalışılmak üzere alıştırmalara yer verilmiştir.

Etkinliklerde müzik kavramları somutlaştırılmıştır.

Nota saplarının yerlerinin değişmesi, sağ ve sol el geçişleri, aynı

anlama gelen farklı işaretlerin kullanılması vb. konularda açıklamalar yapilmıştır.

Okul öncesi eğitim ilkelerinden "basitten karmaşı̆̆a" ilkesine uygun bir ilerleme ele alınmıştır.

Okul öncesi eğitim ilkelerinden "bilinenden bilinmeyene" ilkesine uygun bir ilerleme ele alınmıștır.

Okul öncesi eğitim ilkelerinden "somuttan soyuta" ilkesine uygun bir ilerleme ele alınmıştır. 
Tablo 16'nın devamı

\begin{tabular}{|c|c|c|c|c|c|c|c|c|c|c|}
\hline Bilişsel Gelişim Özellikleri & 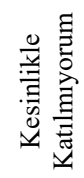 & $\partial^{\circ}$ & 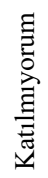 & $\therefore$ & 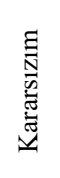 & $\partial^{\circ}$ & 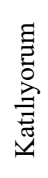 & $a^{\circ}$ & 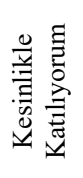 & $a^{\circ}$ \\
\hline $\begin{array}{l}\text { Okul öncesi eğitim ilkelerinden "nesnellik ve açıklık" ilkesine uygun } \\
\text { bir ilerleme ele alınmıştır. }\end{array}$ & - & - & - & - & - & - & - & - & 5 & 100 \\
\hline \multicolumn{11}{|l|}{ Sosyal ve Duygusal Gelişim Özellikleri } \\
\hline $\begin{array}{l}\text { Çocuğu piyano başında sıkmadan, çocuğun canını acıtacak kadar } \\
\text { parmaklarını yormadan, onu mutlu edip eğlendirecek özelliklere } \\
\text { sahiptir. }\end{array}$ & - & - & - & - & - & - & - & - & 5 & 100 \\
\hline $\begin{array}{l}\text { Öğretmeniyle veya piyano dersi alan başka bir arkadaşıyla birlikte } \\
\text { çalma etkinliklerine yer verilmiştir. }\end{array}$ & - & - & - & - & - & - & 1 & 20 & 4 & 80 \\
\hline $\begin{array}{l}\text { Doğaçlama, birlikte çalma vb. etkinliklerle çocuğun girişkenliğini öne } \\
\text { çıkaracak çalışmalara yer verilmiştir. }\end{array}$ & 1 & 20 & - & - & - & - & 2 & 40 & 2 & 40 \\
\hline $\begin{array}{l}\text { Metot aileyi öğrenme sürecine dahil eder ve çocuğun evde düzenli } \\
\text { çalışması ile ilgili aile denetimi istenmiştir. }\end{array}$ & 4 & 80 & - & - & - & - & - & - & 1 & 20 \\
\hline $\begin{array}{l}\text { Oyun gelişimi ve yaratıcılığı destekleyen çocuk merkezli etkinliklere } \\
\text { yer verilmiştir. }\end{array}$ & - & - & - & - & - & - & - & - & 5 & 100 \\
\hline
\end{tabular}

Tablo 16'da uzmanların verdikleri cevaplar doğrultusunda Lesson Book B kitabının gelişimsel özelliklerinin hedef kitleye çoğunlukla uyumlu olduğu görülmektedir. Fiziksel gelişim özelliklerine bakıldığında kitapta; çocuğun piyano başında oturuşu ile ilgili kas, iskelet sağlı̆̆ını koruyucu uyarılara rastlanılmakta ancak ayağın altına tabure koyulması ile ilgili herhangi bir bilgilendirmeye rastlanmamıştır. Çocukların ellerini yumruk yaptırarak tuşlar üzerinde etkinlikler yaptırılmamıştır. İlk kitapta bu etkinlikler vardı ancak bu ikinci kitap olduğu için bulunmamaktadır. Çocukların daha güçlü olan 1 ve 2 numaraları parmaklarını kullandığı etkinliklere daha fazla yer verildiği ve bu doğrultuda çocukların daha zayıf olan 4 ve 5 numaraları parmaklarının kullanımlarına ilerleyen etkinliklerde verildiği görülmektedir. Çocukların görme becerilerine uygun olarak küçük ve ayrıntılı figürlerden kaçılmış ve büyük figürlere yer verilmiştir. Renk seçimi ve tonlamasında karmaşık olmayan bir yaklaşım izlenmiştir. Bilişsel gelişim özellikleri ele alındığında kitapta; piyano ile arkadaş olmaya yönelik temaların işlendiği ve dil gelişimine fayda sağlayacak çalışmalara yer verildiği görülmektedir. Dizeksiz nota eğitimine yer verildiği ve ilerledikçe dizekli nota eğitimine geçildiği görülmüştür. Dikkat dağıtmayan sayfa planlamaları yapıldığı görülmektedir. Etkinlik başlarında eski konuların tekrarına ve etkinlik sonlarında yeni konuya hazırlayıcı çalışmalara yer verilmiştir. Ancak işlenilen etkinlikler doğrultusunda evde çalışılmak üzere alıştırmalara yer verilmemiştir. Etkinliklerde müzik kavramları somutlaştırılmıştır. Nota saplarının yerlerinin değişmesi, sağ ve sol el geçişleri, aynı anlama gelen farklı işaretlerin kullanılması vb. konuların bir kısmında açıllama yapılmıştır. Okul öncesi eğitim ilkelerinden "basitten karmaşığa", "bilinenden bilinmeyene", "somuttan soyuta", "nesnellik ve açıklık" ilkelerine uygun bir ilerleme ele alınmıştır. Sosyal ve duygusal gelişim özellikleri ele alındığında kitapta; çocuğu piyano başında sıkmadan, çocuğun canını acıtacak kadar parmaklarını yormadan, onu mutlu edip eğlendirecek özelliklere sahip bir ilerleme planlanmıştır. Metotta öğretmeniyle veya piyano dersi alan başka bir arkadaşıyla birlikte çalma etkinliklerine yer verilmiştir. Doğaçlama, birlikte çalma vb. etkinliklerle çocuğun girişkenliğini öne çıkarmak amaçlanmıştır. Oyun gelişimi ve yaratıcılığı destekleyen çocuk merkezli etkinliklere yer verilmiştir. Ancak metot aileyi öğrenme sürecine dahil etmez ve çocuğun evde düzenli çalışması ile ilgili aile denetimi istenmemiştir.

Tablo 17

Nancy Faber ve Randall Faber - My First Piano Adventure: Lesson Book C Metoduna Ait Görsel Özellikler

\begin{tabular}{|c|c|c|c|c|c|c|c|c|c|c|}
\hline Görsel Özellikler & 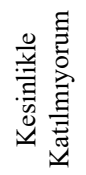 & $a^{\circ}$ & 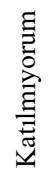 & $0^{\circ}$ & 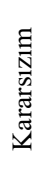 & $0^{\circ}$ & 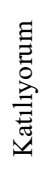 & $\partial^{\circ}$ & 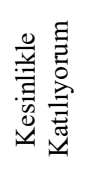 & $a^{\circ}$ \\
\hline Metodun dış kapağ1 güzel planlanmış. & 1 & 20 & - & - & 1 & 20 & 2 & 40 & 1 & 20 \\
\hline Metodun sayfa düzeni planlaması güzel yapılmış. & - & - & - & - & - & - & 4 & 80 & 1 & 20 \\
\hline $\begin{array}{l}\text { Nota, ölçü, dizek, sus, vb. bütün işaretlerin büyüklüğü hedef kitleye } \\
\text { uygun planlanmış. }\end{array}$ & - & - & - & - & - & - & 2 & 40 & 3 & 60 \\
\hline Kullanılan resim ve fotoğraflar hedef kitleye uygun seçilmiş. & - & - & - & - & - & - & 2 & 40 & 3 & 60 \\
\hline $\begin{array}{l}\text { Kullanılan resim ve fotoğraflar renk, boyut, vb. kıstaslar açısından ilgi } \\
\text { çekici. }\end{array}$ & - & - & - & - & - & - & 2 & 40 & 3 & 60 \\
\hline $\begin{array}{l}\text { Kullanılan yazı karakterleri, punto gibi tipografik özellikler hedef } \\
\text { kitleye uygun seçilmiş. }\end{array}$ & - & - & - & - & - & - & 1 & 20 & 4 & 80 \\
\hline
\end{tabular}


Tablo 17'de görüleceği üzere uzmanlar görsel özelliklere ilişkin kriterlerin çoğuna katılmaktadır. Buna göre, Lesson Book C kitabının dış kapağı ve sayfa düzeni güzel planlanmıştır. Nota, ölçü, dizek, sus, vb. bütün işaretlerin büyüklükleri çocuklar için uygundur. Kullanılan resim ve fotoğraflar hedef kitleye uygun seçilmiştir. Kullanılan resim ve fotoğraflar renk, boyut, vb. kıstaslar çocuklar için ilgi çekicidir. Kullanılan yazı karakterleri, punto gibi tipografik özellikler de hedef kitleye uygundur.

\section{Tablo 18}

Nancy Faber ve Randall Faber - My First Piano Adventure: Lesson Book C Metoduna Ait Teknik Özellikler

\begin{tabular}{|c|c|c|c|c|c|c|c|c|c|c|}
\hline Teknik Özellikler & 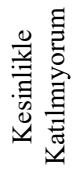 & $\overbrace{}^{0}$ & 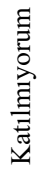 & $a^{\circ}$ & 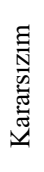 & $0^{\circ}$ & 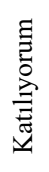 & $\partial^{\circ}$ & 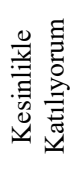 & $\overbrace{}^{\circ}$ \\
\hline Doğru parmak, el, bilek, dirsek duruşları ile ilgili bilgiler verilmiş. & - & - & - & - & - & - & - & - & 5 & 100 \\
\hline Piyano başında doğru oturuş ve duruş ile ilgili bilgiler verilmiş. & - & - & - & - & - & - & - & - & 5 & 100 \\
\hline Doğru parmak numaraları belirli aralıklarla hatırlatılmış. & - & - & - & - & - & - & - & - & 5 & 100 \\
\hline İki elin birlikte kullanımına yer verilmiştir. & - & - & - & - & - & - & - & - & 5 & 100 \\
\hline Bağlı - kesik çalma ile ilgili çalışmalar yapılmış. & 1 & 20 & 2 & 40 & 2 & 40 & - & - & - & - \\
\hline Çift ses çalışmalarına yer verilmiş. & - & - & - & - & - & - & - & - & 5 & 100 \\
\hline Üç ses - akor çalışmalarına yer verilmiş. & 1 & 20 & 2 & 40 & 2 & 40 & - & - & - & - \\
\hline Dizi çalışmaları ve parmak geçişlerine yer verilmiş. & 5 & 100 & - & - & - & - & - & - & - & - \\
\hline
\end{tabular}

Tablo 18'de uzmanların verdikleri cevaplar doğrultusunda Lesson Book C kitabının teknik özelliklerinin hedef kitleye çoğunlukla uyumlu olduğu görülmektedir. Doğru parmak el, bilek, dirsek duruşları ve piyano başında doğru oturuş, duruş ile ilgili bilgiler fotoğraflarla birlikte metotta vardır. Doğru parmak numaralarının belirli aralıklarla hatırlatılmıştır. İki elin birlikte kullanılması ve çift ses çalışmaları metotta yer almıştır. Metotta bağlıkesik çalma ile ilgili çalışmalar, üç ses-akor çalışmaları, dizi çalışmaları ve parmak geçişleri ile ilgili herhangi bir alıştırma göze çarpmamaktadır.

Tablo 19

Nancy Faber ve Randall Faber - My First Piano Adventure: Lesson Book C Metoduna Ait Müzikal ve Teorik Özellikler

\begin{tabular}{|c|c|c|c|c|c|c|c|c|c|c|}
\hline Müzikal ve Teorik Özellikler & 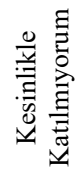 & $0^{\circ}$ & 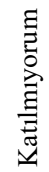 & $\gtrsim^{\circ}$ & 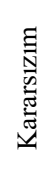 & $\partial^{\circ}$ & 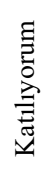 & $\partial^{\circ}$ & 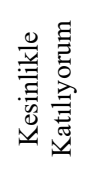 & $d^{\circ}$ \\
\hline İçindekiler veya öneriler kısmı ile öğretmen yönlendirilmiş. & - & - & - & - & - & - & - & - & 5 & 100 \\
\hline Temel müzik bilgilerine yer verilmiş. & - & - & - & - & - & - & - & - & 5 & 100 \\
\hline Hedef kitleye uygun nota öğretimi seçilmiş. & - & - & - & - & - & - & - & - & 5 & 100 \\
\hline Çeşitli bestecilerin eserlerine yer verilmiş. & - & - & - & - & - & - & - & - & 5 & 100 \\
\hline Besteci ve dönemler hakkında bilgiler verilmiş. & - & - & - & - & - & - & - & - & 5 & 100 \\
\hline Metot sistematik, sıralı ve planlı bir şekilde tasarlanmış. & - & - & - & - & - & - & - & - & 5 & 100 \\
\hline Öğretmen eşliğine yer verilmiş. & - & - & - & - & - & - & - & - & 5 & 100 \\
\hline Dört el çalışmalarına yer verilmiş. & 5 & 100 & - & - & - & - & - & - & - & - \\
\hline Doğaçlama çalışmalara yer verilmiş. & 5 & 100 & - & - & - & - & - & - & - & - \\
\hline Nota isimleri öğretilmiş. & - & - & - & - & - & - & - & - & 5 & 100 \\
\hline $\begin{array}{l}\text { Öğretilen notalar, anahtarlar, suslar, nüans terimleri, hız terimleri vb. } \\
\text { müzik bilgileri boyama, çizim gibi etkinliklerle pekiștirilmiş. }\end{array}$ & 5 & 100 & - & - & - & - & - & - & - & - \\
\hline Metodun sonunda öğrenciye sertifika verilmiş. & - & - & - & - & - & - & - & - & 5 & 100 \\
\hline Metotla birlikte CD eki verilmiş. & - & - & - & - & - & - & - & - & 5 & 100 \\
\hline Metotla paralel çalışma - ödev kitabı tasarlanmış. & - & - & - & - & - & - & - & - & 5 & 100 \\
\hline
\end{tabular}

Tablo 19'da görüldüğü üzere Lesson Book C kitabında içindekiler veya öneriler kısmı ile öğretmene yönlendirme yapılmıştır. Temel müzik bilgilerine yer verilmiştir. Okul öncesi çocuklara uygun nota öğretimi seçilmiştir. Metotta çeşitli bestecilerin eserlerine, besteci ve dönemler ile ilgili bilgilere yer verilmiştir. Serinin üçüncü kitabı olması ve öğrencinin seviyesinin ilerlemeye başlamasından dolayı bu bilgilere yer verildiği düşünülmektedir. Metot sistematik, sıralı ve planlı bir şekilde tasarlanmıştır. Öğretmen eşliklerine çeşitli parçalarda yer verilmiştir. Dört el çalışmalarına yer verilmemiştir. Doğaçlama çalışmalara yer verilmiştir. Nota isimleri öğretilmiştir ancak öğretilen notalar, anahtarlar, suslar, nüans terimleri, hız terimleri, vb. müzik bilgileri boyama ve çizim gibi etkinliklerle pekiştirilmemiştir. Bu yaş grubu boyama ve çizim gibi etkinlikleri zevkle yapacağ 1 için metotta bulunabilirdi. Metodun sonunda öğrenciye bir sertifika verilecektir. Metotla paralel çalışma - ödev kitabı tasarlanmıştır. Metotla birlikte verilen CD eki günümüz teknolojisi göz önünde bulundurulduğunda doğru bir planlama olmuştur ancak web tabanlı bir uygulamanın olması daha faydalı olacaktır. Evde CD’yi çalıp hem şarkıları dinleyip üstüne söyleyebilir, hem de çalabilir. 
Tablo 20

Nancy Faber ve Randall Faber - My First Piano Adventure: Lesson Book C Metoduna Ait Gelişimsel Özellikler

Gelişimsel Özellikler

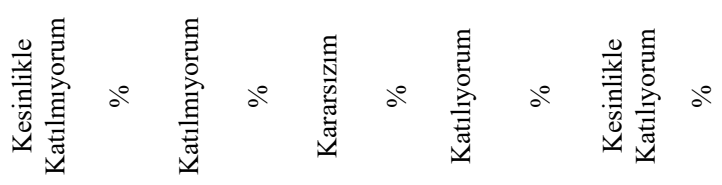

Fiziksel Gelișim Özellikleri

Çocuğun piyano başında oturuşu ile ilgili kas, iskelet sağlığını koruyucu uyarılar yapılmış ve ayağın altına tabure koyulması sağlanmıştır.

Çocukların ellerini yumruk yaptırarak tuşlar üzerinde etkinlikler yapilmıştır.

Çocukların daha güçlü olan 1 ve 2 numaraları parmaklarını kullandığı etkinliklere daha fazla yer verilmiştir.

Çocukların daha zayıf olan 4 ve 5 numaraları parmaklarının kullanımı ilerleyen etkinliklerde verilmistir.

Çocukların görme becerilerine uygun olarak küçük ve ayrıntılı figürlerden kaçılmış, büyük figürlere yer verilmiş.

Renk seçimi ve tonlamasında karmaşık olmayan bir yaklaşım

izlenmiștir.

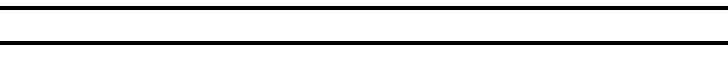

Bilissel Gelişim Özellikleri

Piyano ile arkadaş olmaya yönelik temalar işlenmiştir.

Dil gelişimine fayda sağlayacak çalışmalara yer verilmiştir.

Dizeksiz nota eğitimi ile başlamıştır.

Sade ve dikkat dağıtmayan sayfa planlamaları yapılmıştır.

Etkinliklere başlarken eski konulara yer verilmiştir.

Etkinlik sonlarında sonraki etkinliklere hazırlayıcı çalışmalar

yapılmıştır.

İşlenilen etkinlikler doğrultusunda evde çalışılmak üzere alıştırmalara

yer verilmiştir.

Etkinliklerde müzik kavramları somutlaştırılmıştır.

Nota saplarının yerlerinin değişmesi, sağ ve sol el geçişleri, aynı

anlama gelen farklı işaretlerin kullanılması vb. konularda açıklamalar

yapılmıştır.

Okul öncesi eğitim ilkelerinden "basitten karmaşığa" ilkesine uygun

bir ilerleme ele alınmıştır.

Okul öncesi eğitim ilkelerinden "bilinenden bilinmeyene" ilkesine

uygun bir ilerleme ele alınmıștır.

Okul öncesi eğitim ilkelerinden "somuttan soyuta" ilkesine uygun bir

ilerleme ele alınmıștır.

Okul öncesi eğitim ilkelerinden "nesnellik ve açıklık" ilkesine uygun

bir ilerleme ele alınmıștır.

$\begin{array}{llllllllll}- & - & - & - & 1 & 20 & 4 & 80 & - & - \\ 5 & 100 & - & - & - & - & - & - & - & - \\ - & - & - & - & - & - & - & - & 5 & 100 \\ - & - & - & - & - & - & - & - & 5 & 100 \\ - & - & - & - & - & - & - & - & 5 & 100 \\ - & - & - & - & - & - & - & - & 5 & 100\end{array}$

Sosyal ve Duygusal Gelișim Özellikleri

Çocuğu piyano başında sıkmadan, çocuğun canını acıtacak kadar

parmaklarını yormadan, onu mutlu edip eğlendirecek özelliklere

sahiptir.

Öğretmeniyle veya piyano dersi alan baska bir arkadassıyla birlikte

çalma etkinliklerine yer verilmiştir.

Doğaçlama, birlikte çalma vb. etkinliklerle çocuğun girişkenliğini öne çıkaracak çalışmalara yer verilmiștir.

Metot aileyi öğrenme sürecine dahil eder ve çocuğun evde düzenli

çalıșması ile ilgili aile denetimi istenmiștir.

Oyun gelişimi ve yaratıılığı destekleyen çocuk merkezli etkinliklere yer verilmistir.

$\begin{array}{llllllllll}- & - & - & - & - & - & - & - & 5 & 100 \\ - & - & - & - & - & - & - & - & 5 & 100 \\ - & - & - & - & - & - & 1 & 20 & 4 & 80 \\ 5 & 100 & - & - & - & - & - & - & - & - \\ - & - & - & - & - & - & - & - & 5 & 100\end{array}$

Tablo 20'de uzmanların cevapları 1şı̆̆ında Lesson Book C kitabının gelişimsel özelliklerinin hedef kitleye çoğunlukla uyumlu olduğu görülmektedir. Fiziksel gelişim özelliklerine bakıldığında kitapta; çocuğun piyano başında oturuşu ile ilgili kas, iskelet sağlığını koruyucu uyarılara rastlanılmakta ancak ayağın altına tabure koyulması ile ilgili herhangi bir bilgilendirmeye rastlanmamıştır. Çocukların ellerini yumruk yaptırarak tuşlar üzerinde etkinlikler yaptırılmamıştır. $\mathrm{Bu}$ yaş grubu bu etkinlikleri keyifle yapacağ Çocukların daha güçlü olan 1 ve 2 numaraları parmaklarını kullandığı etkinliklere daha fazla yer verilmiş ve çocukların daha zayıf olan 4 ve 5 numaraları parmaklarının kullanımlarına ilerleyen etkinliklerde yer verilmiştir. Çocukların görme becerilerine uygun olarak küçük ve ayrıntılı figürlerden kaçılmıştır. Büyük figürlere yer verildiği, renk seçimi ve tonlamasında karmaşık olmayan bir yaklaşım izlendiği görülmüştür. Bilişsel gelişim özellikleri ele alındığında kitapta; piyano ile arkadaş olmaya yönelik temaların işlenmiş, dil gelişimine fayda sağlayacak çalışmalara yer verilmiştir. Artık dizeksiz nota eğitimine pek yer verilmediği daha çok dizekli nota eğitimi kullanıldığı göze çarpmaktadır. Dikkat dağıtmayan sayfa planlamaları yapılmıştır. Etkinlik başlarında eski konuların tekrarına, etkinlik sonlarında yeni konuya hazırlayıcı çalışmalara yer verilmiştir. Ancak işlenilen 
etkinlikler doğrultusunda evde çalışılmak üzere alıştırmalara yer verilmemiştir. Etkinliklerde müzik kavramları somutlaştırılmıştır. Nota saplarının yerlerinin değişmesi, sağ ve sol el geçişleri, aynı anlama gelen farklı işaretlerin kullanılması vb. konuların çoğunda açıklama yapılmıştır. Okul öncesi eğitim ilkelerinden "basitten karmaşı̆̆a", "bilinenden bilinmeyene", "somuttan soyuta", "nesnellik ve açıklık" ilkelerine uygun bir ilerleme ele alınmıştır. Sosyal ve duygusal gelişim özellikleri ele alındığında kitapta; çocuğu piyano başında sıkmadan, çocuğun canını acıtacak kadar parmaklarını yormadan, onu mutlu edip eğlendirecek özelliklere sahip bir ilerleme vardır. Metotta öğretmeniyle veya piyano dersi alan başka bir arkadaşıyla birlikte çalma etkinliklerine yer verilmiştir. Doğaçlama, birlikte çalma vb. etkinliklerle çocuğun girişkenliğini öne çıkaracak çalışmalara rastlamak mümkündür. Oyun gelişimi ve yaratıcılığı destekleyen çocuk merkezli etkinliklere yer verilmiştir ancak metot aileyi öğrenme sürecine dahil etmez ve çocuğun evde düzenli çalışması ile ilgili aile denetimi istenmemiştir.

Tablo 21

Nail Yavuzoğlu - Okul Öncesi Piyano Eğitimi Metoduna Ait Görsel Özellikler

\begin{tabular}{|c|c|c|c|c|c|c|c|c|c|c|}
\hline Görsel Özellikler & 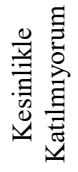 & $a^{\circ}$ & 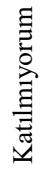 & $a^{\circ}$ & 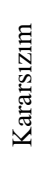 & $a^{\circ}$ & 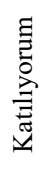 & $a^{\circ}$ & 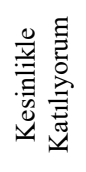 & $a^{\circ}$ \\
\hline Metodun dış kapağ1 güzel planlanmış. & - & - & - & - & - & - & 1 & 20 & 4 & 80 \\
\hline Metodun sayfa düzeni planlaması güzel yapılmış. & - & - & - & - & - & - & - & - & 5 & 100 \\
\hline $\begin{array}{l}\text { Nota, ölçü, dizek, sus, vb. bütün işaretlerin büyüklügü hedef kitleye } \\
\text { uygun planlanmış. }\end{array}$ & - & - & - & - & - & - & - & - & 5 & 100 \\
\hline Kullanılan resim ve fotoğraflar hedef kitleye uygun seçilmiş. & - & - & - & - & - & - & - & - & 5 & 100 \\
\hline $\begin{array}{l}\text { Kullanılan resim ve fotoğraflar renk, boyut, vb. kıstaslar açısından ilgi } \\
\text { çekici. }\end{array}$ & - & - & - & - & - & - & - & - & 5 & 100 \\
\hline $\begin{array}{l}\text { Kullanılan yazı karakterleri, punto gibi tipografik özellikler hedef } \\
\text { kitleye uygun seçilmiş. }\end{array}$ & - & - & - & - & - & - & - & - & 5 & 100 \\
\hline
\end{tabular}

Tablo 21'e bakıldığında uzmanların tamamının görsel özelliklerdeki kriterlere katılıyorum ve kesinlikle katılıyorum cevaplarını verdikleri görülmektedir. Buna göre Nail Yavuzoğlu'nun Okul Öncesi Piyano Eğitimi kitabının bütün görsel özelliklerinin hedef kitleye uyduğu görülmektedir. Metodun dış kapağı ve sayfa düzeni güzel planlanmıştır. Nota, ölçü, dizek, sus, vb. bütün işaretlerin büyüklükleri yanı sıra kullanılan resim ve fotoğraflar hedef yaş grubuna uygundur. Kullanılan resim ve fotoğraflar renk, boyut, vb. kıstaslar çocuklar için ilgi çekicidir. Kullanılan yazı karakterleri, punto gibi tipografik özellikler de hedef kitleye uygun seçilmiştir.

Tablo 22

Nail Yavuzoğlu - Okul Öncesi Piyano Ĕ̌itimi Metoduna Ait Teknik Özellikler

Teknik Özellikler

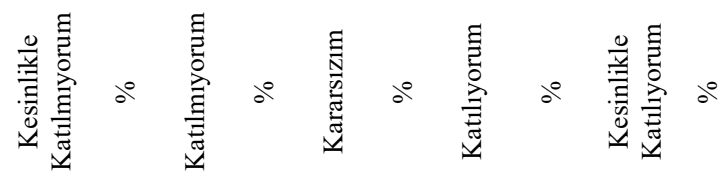

\begin{tabular}{|c|c|c|c|c|c|c|c|c|c|c|}
\hline Doğru parmak, el, bilek, dirsek duruşları ile ilgili bilgiler verilmiş. & - & - & - & - & - & - & 3 & 60 & 2 & 40 \\
\hline Piyano başında doğru oturuş ve duruş ile ilgili bilgiler verilmiş. & - & - & - & - & - & - & 3 & 60 & 2 & 40 \\
\hline Doğru parmak numaraları belirli aralıklarla hatırlatılmış. & - & - & - & - & - & - & - & - & 5 & 100 \\
\hline İki elin birlikte kullanımına yer verilmiştir. & - & - & - & - & - & - & - & - & 5 & 100 \\
\hline Bağlı - kesik çalma ile ilgili çalışmalar yapılmış. & 5 & 100 & - & - & - & - & - & - & - & - \\
\hline Çift ses çalışmalarına yer verilmiş. & 5 & 100 & - & - & - & - & - & - & - & - \\
\hline Üç ses - akor çalışmalarına yer verilmiş. & 5 & 100 & - & - & - & - & - & - & - & - \\
\hline Dizi çalışmaları ve parmak geçişlerine yer verilmiş. & 5 & 100 & - & - & - & - & - & - & - & - \\
\hline
\end{tabular}

Tablo 22'de uzmanların verdikleri cevaplar doğrultusunda Nail Yavuzoğlu'nun Okul Öncesi Piyano Eğitimi kitabının teknik özelliklerinin hedef kitleye kısmen uyumlu olduğu görülmektedir. Doğru parmak el, bilek, dirsek duruşları ve piyano başında doğru oturuş, duruş ile ilgili bilgiler fotoğraflarla desteklenmiştir. Doğru parmak numaraları belirli aralıklarla hatırlatılmıştır. İki elin birlikte kullanılması metotta yer almıştır. Metotta bağlı-kesik çalma ile ilgili çalışmalar, çift ses çalışmaları, üç ses - akor çalışmaları, dizi çalışmaları ve parmak geçişleri ile ilgili herhangi bir alıştırma göze çarpmamaktadır. 
Tablo 23

Nail Yavuzoğlu - Okul Öncesi Piyano Eğitimi Metoduna Ait Müzikal ve Teorik Özellikler

Müzikal ve Teorik Özellikler

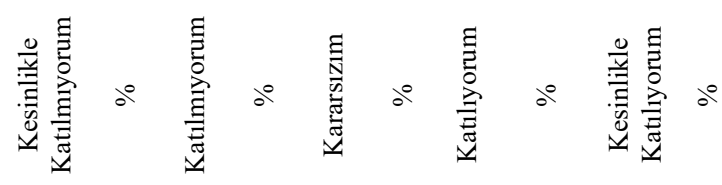

\begin{tabular}{|c|c|c|c|c|c|c|c|c|c|c|}
\hline İçindekiler veya öneriler kısmı ile öğretmen yönlendirilmiş. & 4 & 80 & 1 & 20 & - & - & - & - & - & - \\
\hline Temel müzik bilgilerine yer verilmiş. & - & - & - & - & - & - & - & - & 5 & 100 \\
\hline Hedef kitleye uygun nota öğretimi seçilmiş. & - & - & - & - & - & - & 1 & 20 & 4 & 80 \\
\hline Çeşitli bestecilerin eserlerine yer verilmiş. & - & - & 5 & 100 & - & - & - & - & - & - \\
\hline Besteci ve dönemler hakkında bilgiler verilmiş. & 5 & 100 & - & - & - & - & - & - & - & - \\
\hline Metot sistematik, sıralı ve planlı bir şekilde tasarlanmış. & - & - & - & - & - & - & 1 & 20 & 4 & 80 \\
\hline Öğretmen eşliğine yer verilmiş. & - & - & 1 & 20 & - & - & 1 & 20 & 3 & 60 \\
\hline Dört el çalışmalarına yer verilmiş. & 5 & 100 & - & - & - & - & - & - & - & - \\
\hline Doğaçlama çalışmalara yer verilmiş. & 4 & 80 & - & - & 1 & 20 & - & - & - & - \\
\hline Nota isimleri ögrretilmiş. & - & - & - & - & - & - & - & - & 5 & 100 \\
\hline $\begin{array}{l}\text { Öğretilen notalar, anahtarlar, suslar, nüans terimleri, hız terimleri vb. } \\
\text { müzik bilgileri boyama, çizim gibi etkinliklerle pekiştirilmiş. }\end{array}$ & - & - & - & - & - & - & - & - & 5 & 100 \\
\hline Metodun sonunda öğrenciye sertifika verilmiş. & - & - & - & - & - & - & - & - & 5 & 100 \\
\hline Metotla birlikte CD eki verilmiş. & - & - & - & - & - & - & - & - & 5 & 100 \\
\hline Metotla paralel çalışma - ödev kitabı tasarlanmış. & 5 & 100 & - & - & - & - & - & - & - & - \\
\hline
\end{tabular}

Tablo 23'te uzmanların verdikleri cevaplar doğrultusunda kitabın müzikal ve teorik özelliklerinin hedef kitleye kısmen uyumlu olduğu görülmektedir. Kitapta içindekiler veya öneriler kısmı ile öğretmene yönlendirme yapılmamıştır. Öğretmeni metot ile ilgili bilgilendirmek amacıyla bu yönlendirmeler çok önemlidir. Temel müzik bilgilerine yer verilmiştir ve hedef kitleye uygun nota öğretimi seçilmiştir. Metotta çeşitli bestecilerin eserlerine, besteci ve dönemler ile ilgili bilgilere yer verilmemiştir. Metot sistematik, sıralı ve planlı bir şekilde tasarlanmıştır. Öğretmen eşliklerine çeşitli parçalarda yer verilmiştir. Birlikte müzik yapmak adına öğretmen eşliğinin önemli görülmektedir. Dört el çalışmalarına yer verilmemiştir. Doğaçlama çalışmalara yer verilmemiştir. Nota isimleri öğretilmiştir ve öğretilen notalar, anahtarlar, suslar, nüans terimleri, hız terimleri, vb. müzik bilgileri boyama ve çizim gibi etkinliklerle pekiştirilmiştir. Metodun sonunda öğrenciye bir sertifika verilmesi planlanmıştır. Öğrenciyi motive etmek için önemlidir. Metotla paralel herhangi bir çalışma-ödev kitabı tasarlanmamıştır. Metotla birlikte verilen CD eki günümüz teknolojisi de göz önünde bulundurulduğunda doğru bir planlama olmuştur ancak web tabanlı bir uygulamanın olması daha faydalı olacaktır. Evde çocuk CD'den şarkıları dinleyebilir, söyleyebilir ve çalabilir.

Tablo 24

Nail Yavuzoğlu - Okul Öncesi Piyano Eğitimi Metoduna Ait Gelişimsel Özellikler

Gelişimsel Özellikler $\quad$ 范

\begin{tabular}{|c|c|c|c|c|c|c|c|c|c|c|}
\hline \multicolumn{11}{|l|}{ Fiziksel Gelișim Özellikleri } \\
\hline Çocuğun piyano başında oturuşu ile ilgili kas, iskelet sağlı̆̆ını & & & & & & & & & & \\
\hline $\begin{array}{l}\text { koruyucu uyarılar yapılmış ve ayağın altına tabure koyulması } \\
\text { sağlanmıştır. }\end{array}$ & 5 & 100 & - & - & - & - & - & - & - & - \\
\hline $\begin{array}{l}\text { Çocukların ellerini yumruk yaptırarak tuşlar üzerinde etkinlikler } \\
\text { yapılmıştır. }\end{array}$ & 5 & 100 & - & - & - & - & - & - & - & - \\
\hline $\begin{array}{l}\text { Çocukların daha güçlü olan } 1 \text { ve } 2 \text { numaraları parmaklarını kullandığı } \\
\text { etkinliklere daha fazla yer verilmiştir. }\end{array}$ & - & - & - & - & - & - & - & - & 5 & 100 \\
\hline $\begin{array}{l}\text { Çocukların daha zayıf olan } 4 \text { ve } 5 \text { numaraları parmaklarının kullanımı } \\
\text { ilerleyen etkinliklerde verilmiștir. }\end{array}$ & - & - & - & - & - & - & - & - & 5 & 100 \\
\hline $\begin{array}{l}\text { Çocukların görme becerilerine uygun olarak küçük ve ayrıntılı } \\
\text { figürlerden kaçılmış, büyük figürlere yer verilmiş. }\end{array}$ & - & - & - & - & 1 & 20 & - & - & 4 & 80 \\
\hline $\begin{array}{l}\text { Renk seçimi ve tonlamasında karmaşı olmayan bir yaklaşım } \\
\text { izlenmiștir. }\end{array}$ & - & - & - & - & - & - & - & - & 5 & 100 \\
\hline \multicolumn{11}{|l|}{ Bilişsel Gelişim Özellikleri } \\
\hline Piyano ile arkadaş olmaya yönelik temalar işlenmiştir. & 2 & 40 & 1 & 20 & - & - & 1 & 20 & 1 & 20 \\
\hline Dil gelişimine fayda sağlayacak çalışmalara yer verilmiştir. & - & - & 3 & 60 & 2 & 40 & - & - & - & - \\
\hline Dizeksiz nota eğitimi ile başlamıştır. & - & - & - & - & 1 & 20 & - & - & 4 & 80 \\
\hline Sade ve dikkat dağıtmayan sayfa planlamaları yapılmıştır. & - & - & - & - & - & - & 3 & 60 & 2 & 40 \\
\hline Etkinliklere başlarken eski konulara yer verilmiştir. & - & - & - & - & - & - & 3 & 60 & 2 & 40 \\
\hline $\begin{array}{l}\text { Etkinlik sonlarında sonraki etkinliklere hazırlayıcı çalışmalar } \\
\text { yapılmıştır. }\end{array}$ & - & - & - & - & - & - & 3 & 60 & 2 & 40 \\
\hline
\end{tabular}


Tablo 24'ün devamı

\begin{tabular}{|c|c|c|c|c|c|c|c|c|c|c|}
\hline Bilişsel Gelişim Özellikleri & 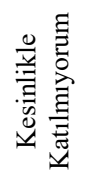 & $a^{\circ}$ & 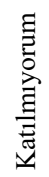 & $\partial^{\circ}$ & 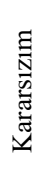 & $a^{\circ}$ & 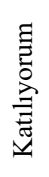 & $\partial^{\circ}$ & 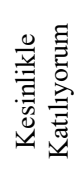 & $\partial^{\circ}$ \\
\hline $\begin{array}{l}\text { İ̧şlenilen etkinlikler doğrultusunda evde çalışılmak üzere alıştırmalara } \\
\text { yer verilmiştir. }\end{array}$ & 5 & 100 & - & - & - & - & - & - & - & - \\
\hline Etkinliklerde müzik kavramları somutlaştırılmıştır. & - & - & - & - & - & - & - & - & 5 & 100 \\
\hline $\begin{array}{l}\text { Nota saplarının yerlerinin değişmesi, sağ ve sol el geçişleri, aynı } \\
\text { anlama gelen farklı işaretlerin kullanılması vb. konularda açıklamalar } \\
\text { yapılmıştır. }\end{array}$ & - & - & - & - & - & - & 5 & $\begin{array}{c}10 \\
0\end{array}$ & - & - \\
\hline $\begin{array}{l}\text { Okul öncesi eğitim ilkelerinden "basitten karmaşı̆̆a" ilkesine uygun } \\
\text { bir ilerleme ele alınmıştır. }\end{array}$ & - & - & - & - & - & - & - & - & 5 & 100 \\
\hline $\begin{array}{l}\text { Okul öncesi eğitim ilkelerinden "bilinenden bilinmeyene" ilkesine } \\
\text { uygun bir ilerleme ele alınmıștır. }\end{array}$ & - & - & - & - & - & - & - & - & 5 & 100 \\
\hline $\begin{array}{l}\text { Okul öncesi eğitim ilkelerinden "somuttan soyuta" ilkesine uygun bir } \\
\text { ilerleme ele alınmıștır. }\end{array}$ & - & - & - & - & - & - & - & - & 5 & 100 \\
\hline $\begin{array}{l}\text { Okul öncesi eğitim ilkelerinden "nesnellik ve açıklık" ilkesine uygun } \\
\text { bir ilerleme ele alınmıştır. }\end{array}$ & - & - & - & - & - & - & - & - & 5 & 100 \\
\hline \multicolumn{11}{|l|}{ Sosyal ve Duygusal Gelişim Özellikleri } \\
\hline $\begin{array}{l}\text { Çocuğu piyano başında sıkmadan, çocuğun canını acıtacak kadar } \\
\text { parmaklarını yormadan, onu mutlu edip eğlendirecek özelliklere } \\
\text { sahiptir. }\end{array}$ & - & - & - & - & - & - & 4 & 80 & 1 & 20 \\
\hline $\begin{array}{l}\text { Öğretmeniyle veya piyano dersi alan başka bir arkadaşıyla birlikte } \\
\text { çalma etkinliklerine yer verilmiştir. }\end{array}$ & - & - & - & - & - & - & 1 & 20 & 4 & 80 \\
\hline $\begin{array}{l}\text { Doğaçlama, birlikte çalma vb. etkinliklerle çocuğun girişkenliğini öne } \\
\text { çıaracak çalışmalara yer verilmiştir. }\end{array}$ & 2 & 40 & 1 & 20 & - & - & 2 & 40 & - & - \\
\hline $\begin{array}{l}\text { Metot aileyi ögrenme sürecine dahil eder ve çocuğun evde düzenli } \\
\text { çalıșması ile ilgili aile denetimi istenmiștir. }\end{array}$ & 5 & 100 & - & - & - & - & - & - & - & - \\
\hline $\begin{array}{l}\text { Oyun gelişimi ve yaratıcılığı destekleyen çocuk merkezli etkinliklere } \\
\text { yer verilmiştir. }\end{array}$ & - & - & - & - & - & - & 5 & $\begin{array}{c}10 \\
0\end{array}$ & - & - \\
\hline
\end{tabular}

Tablo 24'te uzmanların verdikleri cevaplar doğrultusunda kitabın gelişimsel özelliklerinin hedef kitleye kısmen uyumlu olduğu görülmektedir. Fiziksel gelişim özelliklerine bakıldığında kitapta; çocuğun piyano başında oturuşu ile ilgili kas, iskelet sağlığını koruyucu uyarılara ve ayağın altına tabure koyulması ile ilgili herhangi bir bilgilendirmeye rastlanmamıştır. Çocukların ellerini yumruk yaptırarak tuşlar üzerinde etkinlikler yaptırıldığı görülmüştür. Çocukların daha güçlü olan 1 ve 2 numaraları parmaklarını kullandığı etkinliklere daha fazla yer verilmiştir. Çocukların daha zayıf olan 4 ve 5 numaraları parmaklarının kullanımlarına ise ilerleyen etkinliklerde verildiği görülmektedir. Çocukların görme becerilerine uygun olarak küçük ve ayrıntılı figürlerden kaçılmış ve büyük figürlere yer verilmiştir. Renk seçimi ve tonlamasında karmaşık olmayan bir yaklaşım izlenmiştir. Bilişsel gelişim özellikleri ele alındığında kitapta; piyano ile arkadaş olmaya yönelik temaların işlenmediği ve dil gelişimine fayda sağlayacak çalışmalara yer verilmediği görülmüştür. Bu çalışmalar önemlidir ancak metotta bulunmamaktadır. Dizeksiz nota eğitimine yer verildiği ve dikkat dağıtmayan sayfa planlamaları yapıldığı görülmektedir. Etkinlik başlarında eski konuların tekrarına, etkinlik sonlarında ise yeni konuya hazırlayıcı çalışmalara yer verilmiştir. İşlenilen etkinlikler doğrultusunda evde çalışılmak üzere alıştırmalar bulunmamaktadır. Etkinliklerde müzik kavramları somutlaştırılmıştır. Nota saplarının yerlerinin değişmesi, sağ ve sol el geçişleri, aynı anlama gelen farklı işaretlerin kullanılması vb. konuların çoğunda açıklama yapılmıştır. Okul öncesi eğitim ilkelerinden "basitten karmaşı̆̆a", "bilinenden bilinmeyene", "somuttan soyuta", "nesnellik ve açıklık" ilkelerine uygun bir ilerleme ele alınmıştır. Sosyal ve duygusal gelişim özellikleri ele alındığında kitapta; çocuğu piyano başında sıkmadan, çocuğun canını acıtacak kadar parmaklarını yormadan, onu mutlu edip eğlendirecek özelliklere sahip bir ilerleme görülmektedir. Metotta öğretmeniyle veya piyano dersi alan başka bir arkadaşıyla birlikte çalma etkinliklerine yer verilmiştir. Doğaçlama, birlikte çalma vb. etkinliklerle çocuğun girişkenliğini öne çıkaracak çalışmalar vardır. Oyun gelişimi ve yaratıcılığı destekleyen çocuk merkezli etkinliklere yer verilmiştir. Metot aileyi öğrenme sürecine dahil etmez ve çocuğun evde düzenli çalışması ile ilgili aile denetimi istenmemiştir. 
Tablo 25

Yalçın İman - Okul Öncesi Çocuklar İçin Piyano Metoduna Ait Görsel Özellikler

Görsel Özellikler

Metodun diş kapağı güzel planlanmıș.

Metodun sayfa düzeni planlaması güzel yapılmış.

Nota, ölçü, dizek, sus, vb. bütün işaretlerin büyüklüğü hedef kitleye

uygun planlanmış.

Kullanılan resim ve fotoğraflar hedef kitleye uygun seçilmiş.

Kullanılan resim ve fotoğraflar renk, boyut, vb. kıstaslar açısından ilgi

çekici.

Kullanılan yazı karakterleri, punto gibi tipografik özellikler hedef

kitleye uygun seçilmiş.

Tablo 25'e bakıldığında uzmanların farklı cevaplar verdikleri görülmektedir. Buna göre Yalçın İman'ın Okul Öncesi Çocuklar İçin Piyano Metodu'nun görsel özelliklerinin hedef kitleye uymadığı görülmektedir. Metodun dış kapağı göze hoş gelmektedir, ancak sayfa düzeni güzel planlanmamıştır. Diğer taraftan nota, ölçü, dizek, sus, vb. bütün işaretlerin büyüklükleri yanı sıra kullanılan resim ve fotoğraflar hedef kitleye uygun seçilmiştir. Kullanılan resim ve fotoğraflar renk, boyut, vb. kıstaslar açısından ilgi çekicidir. Kullanılan yazı karakterleri, punto gibi tipografik özellikler de yaş grubuna uygundur.

Tablo 26

Yalçın İman - Okul Öncesi Çocuklar İçin Piyano Metoduna Ait Teknik Özellikler

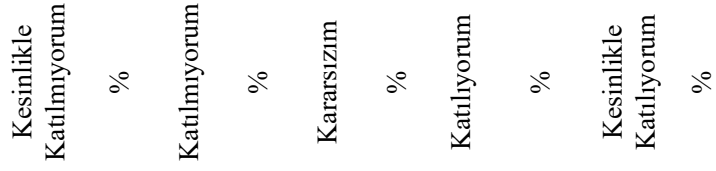

\begin{tabular}{|c|c|c|c|c|c|c|c|c|c|c|}
\hline Doğru parmak, el, bilek, dirsek duruşları ile ilgili bilgiler verilmiş. & 5 & 100 & - & - & - & - & - & - & - & - \\
\hline Piyano başında doğru oturuş ve duruş ile ilgili bilgiler verilmiş. & 5 & 100 & - & - & - & - & - & - & - & - \\
\hline Doğru parmak numaraları belirli aralıklarla hatırlatılmış. & - & - & - & - & - & - & 1 & 20 & 4 & 80 \\
\hline İki elin birlikte kullanımına yer verilmiştir. & - & - & - & - & - & - & - & - & 5 & 100 \\
\hline Bağlı - kesik çalma ile ilgili çalışmalar yapılmış. & - & - & - & - & - & - & 5 & 100 & - & - \\
\hline Çift ses çalışmalarına yer verilmiş. & - & - & - & - & - & - & 5 & 100 & - & - \\
\hline Üç ses - akor çalışmalarına yer verilmiş. & 5 & 100 & - & - & - & - & - & - & - & - \\
\hline Dizi çalışmaları ve parmak geçişlerine yer verilmiş. & 5 & 100 & - & - & - & - & - & - & - & - \\
\hline
\end{tabular}

Tablo 26'da uzmanların verdikleri cevaplar doğrultusunda kitabın teknik özelliklerinin hedef kitleye kısmen uyumlu olduğu görülmektedir. Doğru parmak el, bilek, dirsek duruşları ve piyano başında doğru oturuş, duruş ile ilgili bilgiler metotta bulunmamaktadır. Doğru parmak numaralarının belirli aralıklarla hatırlatılması ve iki elin birlikte kullanılması metotta yer almıştır. Metotta bağl1-kesik çalma ile ilgili çalışmalar, çift ses çalışmalarına yer verilmiştir. Üç ses-akor çalışmaları, dizi çalışmaları ve parmak geçişleri ile ilgili herhangi bir alıştırma göze çarpmamaktadır.

Tablo 27

Yalçın İman - Okul Öncesi Çocuklar İçin Piyano Metoduna Ait Müzikal ve Teorik Özellikler

Müzikal ve Teorik Özellikler

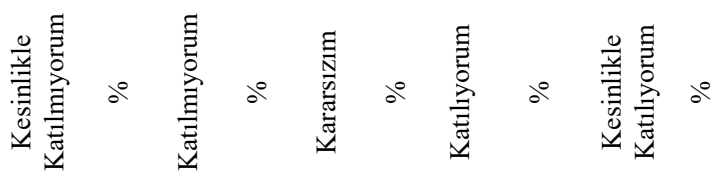

\begin{tabular}{|c|c|c|c|c|c|c|c|c|c|c|}
\hline İçindekiler veya öneriler kısmı ile öğretmen yönlendirilmiş. & - & - & 1 & 20 & - & - & 4 & 80 & - & - \\
\hline Temel müzik bilgilerine yer verilmiş. & - & - & - & - & - & - & 1 & 20 & 4 & 80 \\
\hline Hedef kitleye uygun nota öğretimi seçilmiş. & - & - & 1 & 20 & - & - & 4 & 80 & - & - \\
\hline Çeşitli bestecilerin eserlerine yer verilmiş. & 5 & 100 & - & - & - & - & - & - & - & - \\
\hline Besteci ve dönemler hakkında bilgiler verilmiş. & 5 & 100 & - & - & - & - & - & - & - & - \\
\hline Metot sistematik, sıralı ve planlı bir şekilde tasarlanmış. & - & - & - & - & - & - & 3 & 60 & 2 & 40 \\
\hline Öğretmen eşliğine yer verilmiş. & 5 & 100 & - & - & - & - & - & - & - & - \\
\hline Dört el çalıșmalarına yer verilmiș & 5 & 100 & - & - & - & - & - & - & - & . \\
\hline
\end{tabular}


Tablo 27'nin devamı

\begin{tabular}{|c|c|c|c|c|c|c|c|c|c|c|}
\hline Müzikal ve Teorik Özellikler & 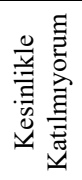 & $a^{\circ}$ & 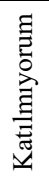 & $0^{\circ}$ & 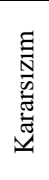 & $d^{\circ}$ & 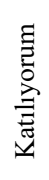 & $\partial^{0}$ & 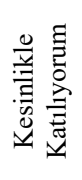 & $0^{\circ}$ \\
\hline Doğaçlama çalışmalara yer verilmiş. & 5 & 100 & - & - & - & - & - & - & - & - \\
\hline Nota isimleri öğretilmiş. & - & - & - & - & - & - & - & - & 5 & 100 \\
\hline $\begin{array}{l}\text { Öğretilen notalar, anahtarlar, suslar, nüans terimleri, hız terimleri vb. } \\
\text { müzik bilgileri boyama, çizim gibi etkinliklerle pekiştirilmiş. }\end{array}$ & 1 & 20 & 2 & 40 & - & - & 2 & 40 & - & - \\
\hline Metodun sonunda öğrenciye sertifika verilmiş. & 5 & 100 & - & - & - & - & - & - & - & - \\
\hline Metotla birlikte $C D$ eki verilmiş. & 5 & 100 & - & - & - & - & - & - & - & - \\
\hline Metotla paralel çalışma - ödev kitabı tasarlanmış. & 5 & 100 & - & - & - & - & - & - & - & - \\
\hline
\end{tabular}

Tablo 27'de uzmanların verdikleri cevaplar doğrultusunda kitabın müzikal ve teorik özelliklerinin hedef kitleye çoğunlukla uyumsuz olduğu görülmektedir. Kitapta içindekiler veya öneriler kısmı ile öğretmene yönlendirme yapılmıştır. Temel müzik bilgilerine yer verilmiştir. Yaş grubuna uygun nota öğretimi seçilmiştir. Metotta çeşitli bestecilerin eserlerine, besteci ve dönemler ile ilgili bilgilere yer verilmemiştir. Bu bilgiler için erken olduğu düşünülmektedir. Metot sistematik, sıralı ve planlı bir şekilde tasarlanmıştır. Öğretmen eşliklerine yer verilmemiştir. Öğretmen eşliklerinin olmasında fayda bulunmaktadır. Dört el çalışmalarına yer verilmemiştir. Doğaçlama çalışmalara yer verilmemiştir. Nota isimleri öğretilmiştir. Ancak öğretilen notalar, anahtarlar, suslar, nüans terimleri, hız terimleri, vb. müzik bilgileri boyama ve çizim gibi etkinliklerle pekiştirilmemiştir. Metodun sonunda öğrenciye bir sertifika verilmesi planlanmamıştır. Metotla paralel herhangi bir çalışma - ödev kitabı tasarlanmamıştır ve metotla birlikte CD eki verilmemiştir. Günümüz teknoloji çağında çocuğun evde CD veya web tabanlı bir uygulama yoluyla dinleme, çalma gibi pekiştirme çalışmaları yapması beklenmektedir. Bu metotta CD eki veya web tabanlı bir uygulama olmaması büyük bir eksiklik olarak göze çarpmaktadır.

Tablo 28

Yalçın İman-Okul Öncesi Çocuklar İçin Piyano Metoduna Ait Gelişimsel Özellikler

Gelişimsel Özellikler

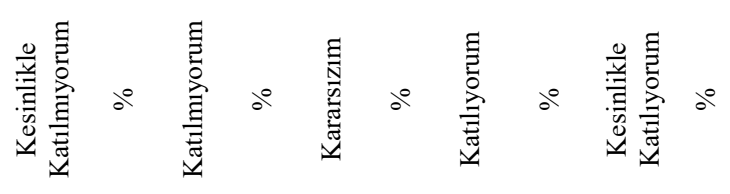

\section{Fiziksel Gelişim Özellikleri}

Çocuğun piyano başında oturuşu ile ilgili kas, iskelet sağlı̆̆ını koruyucu uyarılar yapılmış ve ayağın altına tabure koyulması sağlanmıştır.

Çocukların ellerini yumruk yaptırarak tuşlar üzerinde etkinlikler yapilmıştır

Çocukların daha güçlü olan 1 ve 2 numaraları parmaklarını kullandığı etkinliklere daha fazla yer verilmiştir.

Çocukların daha zayıf olan 4 ve 5 numaraları parmaklarının kullanımı ilerleyen etkinliklerde verilmiştir.

Çocukların görme becerilerine uygun olarak küçük ve ayrıntılı figürlerden kaçılmıs, büyük figürlere yer verilmiș.

Renk seçimi ve tonlamasında karmaşık olmayan bir yaklaşım izlenmiștir.

$\begin{array}{lllllllllll}5 & 100 & - & - & - & - & - & - & - & - \\ 5 & 100 & - & - & - & - & - & - & - & - \\ - & - & - & - & - & - & 1 & 20 & 4 & 80 \\ - & - & - & - & - & - & 1 & 20 & 4 & 80 \\ - & - & - & - & - & - & 1 & 20 & 4 & 80\end{array}$

Bilișsel Gelișim Özellikleri

Piyano ile arkadaş olmaya yönelik temalar işlenmiştir.

Dil gelişimine fayda sağlayacak çalışmalara yer verilmiştir.

Dizeksiz nota eğitimi ile başlamıştır.

Sade ve dikkat dağıtmayan sayfa planlamaları yapılmıştır.

Etkinliklere başlarken eski konulara yer verilmiştir.

Etkinlik sonlarında sonraki etkinliklere hazırlayıcı çalışmalar

yapılmıştır.

İşlenilen etkinlikler doğrultusunda evde çalışılmak üzere alıştırmalara yer verilmiștir.

Etkinliklerde müzik kavramları somutlaştırılmıştır.

Nota saplarının yerlerinin değişmesi, sağ ve sol el geçişleri, aynı

anlama gelen farklı işaretlerin kullanılması vb. konularda açıklamalar yapilmıştır.

Okul öncesi eğitim ilkelerinden "basitten karmaşı̆̆a" ilkesine uygun bir ilerleme ele alınmıştır.

Okul öncesi eğitim ilkelerinden "bilinenden bilinmeyene" ilkesine uygun bir ilerleme ele alınmıștır.

Okul öncesi eğitim ilkelerinden "somuttan soyuta" ilkesine uygun bir ilerleme ele alınmıştır.

\begin{tabular}{|c|c|c|c|c|c|c|c|c|c|}
\hline 2 & 40 & - & - & 1 & 20 & 2 & 40 & - & - \\
\hline 3 & 60 & 2 & 40 & - & - & - & - & - & - \\
\hline 5 & 100 & - & - & - & - & - & - & - & - \\
\hline 5 & 100 & - & - & - & - & - & - & - & - \\
\hline- & - & - & - & 1 & 20 & 2 & 40 & 2 & 40 \\
\hline- & - & - & - & 1 & 20 & 2 & 40 & 2 & 40 \\
\hline 5 & 100 & - & - & - & - & - & - & - & - \\
\hline 1 & 20 & - & - & 1 & 20 & 2 & 40 & 1 & 20 \\
\hline 4 & 80 & 1 & 20 & - & - & - & - & - & - \\
\hline- & - & - & - & 1 & 20 & 1 & 20 & 3 & 60 \\
\hline- & - & - & - & 1 & 20 & 1 & 20 & 3 & 60 \\
\hline- & - & - & - & 1 & 20 & 1 & 20 & 3 & 60 \\
\hline
\end{tabular}


Tablo 28'in devamı

\begin{tabular}{|c|c|c|c|c|c|c|c|c|c|c|}
\hline Bilişsel Gelişim Özellikleri & 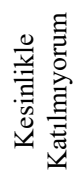 & $a^{\circ}$ & 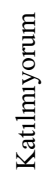 & $\partial^{\circ}$ & 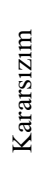 & $\partial^{\circ}$ & 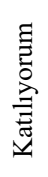 & $\partial^{\circ}$ & 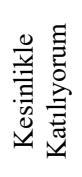 & $a^{\circ}$ \\
\hline $\begin{array}{l}\text { Okul öncesi eğitim ilkelerinden "nesnellik ve açıklık" ilkesine uygun } \\
\text { bir ilerleme ele alınmıştır. }\end{array}$ & - & - & - & - & 1 & 20 & 1 & 20 & 3 & 60 \\
\hline \multicolumn{11}{|l|}{ Sosyal ve Duygusal Gelișim Özellikleri } \\
\hline $\begin{array}{l}\text { Çocuğu piyano başında sıkmadan, çocuğun canını acıtacak kadar } \\
\text { parmaklarını yormadan, onu mutlu edip eğlendirecek özelliklere } \\
\text { sahiptir. }\end{array}$ & - & - & 1 & 20 & 2 & 40 & 1 & 20 & 1 & 20 \\
\hline $\begin{array}{l}\text { Öğretmeniyle veya piyano dersi alan başka bir arkadaşıyla birlikte } \\
\text { çalma etkinliklerine yer verilmiştir. }\end{array}$ & 5 & 100 & - & - & - & - & - & - & - & - \\
\hline $\begin{array}{l}\text { Doğaçlama, birlikte çalma vb. etkinliklerle çocuğun girişkenliğini öne } \\
\text { çıaracak çalışmalara yer verilmiştir. }\end{array}$ & 5 & 100 & - & - & - & - & - & - & - & - \\
\hline $\begin{array}{l}\text { Metot aileyi öğrenme sürecine dahil eder ve çocuğun evde düzenli } \\
\text { çalıșması ile ilgili aile denetimi istenmiștir. }\end{array}$ & 5 & 100 & - & - & - & - & - & - & - & - \\
\hline $\begin{array}{l}\text { Oyun gelişimi ve yaratıcılığ } 1 \text { destekleyen çocuk merkezli etkinliklere } \\
\text { yer verilmiştir. }\end{array}$ & - & - & 2 & 40 & 3 & 60 & - & - & - & - \\
\hline
\end{tabular}

Tablo 28'de uzmanların verdikleri cevaplar doğrultusunda İman'ın kitabının gelişimsel özelliklerinin çoğunlukla uyumlu olmadığı görülmektedir. Fiziksel gelişim özelliklerine bakıldığında kitapta; çocuğun piyano başında oturuşu ile ilgili kas, iskelet sağlığını koruyucu uyarılara ve ayağın altına tabure koyulması ile ilgili herhangi bir bilgilendirmeye rastlanmamıştır. Çocukların ellerini yumruk yaptırarak tuşlar üzerinde etkinlikler yaptırılmamıştır. Bu etkinlikleri çocuklar zevk alarak yaptığı için metotta bulunabilirdi. Çocukların daha güçlü olan 1 ve 2 numaraları parmaklarını kullandığı etkinliklere daha fazla yer verildiği, çocukların daha zayıf olan 4 ve 5 numaraları parmaklarının kullanımlarına ilerleyen etkinliklerde verildiği görülmektedir. Çocukların görme becerilerine uygun olarak küçük ve ayrıntılı figürlerden kaçılmamış ve büyük figürlere yer verilmemiştir. Renk seçimi ve tonlamasında da karmaşık bir yaklaşım izlenmiştir. Metotta hedef yaş grubundaki çocuğun dikkatini dağıtacak çok etken bulunmaktadır. Bilişsel gelişim özellikleri ele alındığında kitapta; piyano ile arkadaş olmaya yönelik temaların işlendiği ancak dil gelişimine fayda sağlayacak çalışmalara yer verilmediği görülmektedir. Dizeksiz nota eğitimine yer verilmemiştir. Okul öncesi yaş grubuna uygun bir nota eğitimi görülmemektedir. Sade ve dikkat dağıtmayan sayfa planlamaları yapılmamıştır. Etkinlik başlarında eski konuların tekrarına, etkinlik sonlarında yeni konuya hazırlayıcı çalışmalara yer verilmiştir. Ancak işlenilen etkinlikler doğrultusunda evde çalışılmak üzere alıştırmalara yer verilmemiştir. Etkinliklerde müzik kavramları somutlaştırılmıştır. Nota saplarının yerlerinin değişmesi, sağ ve sol el geçişleri, aynı anlama gelen farklı işaretlerin kullanılması vb. konuların neredeyse hiçbirinde açıklama yapılmamıştır. Okul öncesi eğitim ilkelerinden "basitten karmaşı̆̆a", "bilinenden bilinmeyene", "somuttan soyuta", "nesnellik ve açıklık” ilkelerine uygun bir ilerleme ele alınmıştır. Sosyal ve duygusal gelişim özellikleri ele alındığında kitapta; çocuğu piyano başında sıkmadan, çocuğun canını acıtacak kadar parmaklarını yormadan, onu mutlu edip eğlendirecek özelliklere sahip bir ilerleme söz konusudur. Metotta öğretmeniyle veya piyano dersi alan başka bir arkadaşıyla birlikte çalma etkinliklerine yer verilmemiştir. Doğaçlama, birlikte çalma vb. etkinliklerle çocuğun girişkenliğini öne çıkaracak çalışmalar da görülmemektedir. Oyun gelişimi ve yaratıcılığı destekleyen çocuk merkezli etkinlikler bulunmamaktadır. Metot aileyi öğrenme sürecine dahil etmez ve çocuğun evde düzenli çalışması ile ilgili aile denetimi istenmemiştir. Metotta birçok konuda eksiklikler görülmektedir.

\section{Sonuc}

Okul öncesi piyano metotlarının erken çocukluk dönemi gelişim basamakları açısından incelenmesinin amaçlandığı bu araştırmada elde edilen sonuçlar aşağıdaki gibidir:

1) Bastiens' Invitation to Music metodunun Piano Party A ve Piano Party B kitapları belirlenen görsel özelliklerin hepsine uymaktadır. Teknik, müzikal ve teorik özelliklerin çoğunluğuna uyum gözlemlenmiştir. Fiziksel ve bilişsel gelişim özelliklerinin neredeyse tamamına uyum sağlamakta olan kitap, sosyal ve duygusal gelişim özelliklerine tamamen uymaktadır.

2) My First Piano Adventure metodunun Lesson Book A ve Lesson Book B kitapları görsel ve teknik özelliklerin hepsine uymaktadır. Müzikal ve teorik özellikler ele alındığında birkaç eksik dışında kitabın bütün özelliklere uyumlu olduğu gözlemlenmiştir. Fiziksel, bilişsel, sosyal ve duygusal gelişim özelliklerine uyumlu olduğu görülmektedir.

3) Yavuzoğlu'nun yazmış olduğu Okul Öncesi Piyano Eğitimi adlı metot görsel ve teknik özelliklere tamamen uymaktadır. Müzikal ve teorik özelliklere kısmen uyum sağladığı görülmektedir. Fiziksel, bilişsel, sosyal ve duygusal gelişim özelliklerinin neredeyse tamamıyla uyumludur. 
4) İman'ın hazırlamış olduğu Okul Öncesi Çocuklar İçin Piyano Metodu görsel özelliklere çoğunlukla uymasına rağmen teknik, müzikal ve teorik özelliklere fazla uyum sağlamadığı görülmektedir. Fiziksel ve bilişsel gelişim özelliklerine pek uyum sağladığ 1 görülmemekle birlikte sosyal ve duygusal gelişim özelliklerine çoğunlukla uyumludur.

Bu sonuçlardan çıkarım yapıldığında incelenen okul öncesi piyano metotlar arasında eksiksiz, her anlamda çok iyi hazırlanmış, mükemmel bir metodun olmadığı görülmüştür. Kaynak (2004) piyano metotlarının; genel ilkeler, eğitimciye rehberlik, izledikleri yöntemler, teknik beceri kazandırma, müzikal ve görsel ögeler yönlerinden incelendiği zaman hiçbir metodun eksiksiz ve en iyi olarak nitelendirilemeyeceğini belirtmiştir. Bu doğrultuda her iki çalışma birbirini destekler niteliktedir.

Çağlak ve Ercan (2017) başlangıç piyano metotlarını müzikal, teknik ve teorik özellikler bakımından incelemiştir. Belirlenen inceleme kriterlerine bakıldığı zaman görsel ögelere yer verilmesi, duruş ve oturuş bilgisi, el tutuş pozisyon bilgisi, öğretmen eşliği, dört el çalışmaları, legato ve staccato çalışmaları, akor çalışmaları gibi her iki çalışmada bulunan kriterler göze çarpmıştır. Işıkdemir'in (2017) çalışmasına bakıldığında ise teknik ve teorik kazanım tabloları görülmektedir. Oturuş, duruş, elin duruşu, legato ve staccato çalışmaları, dizi çalışmaları ve parmak geçişleri, çift ses çalışmaları, akor çalışmaları, temel müzik bilgileri, resimlerle destekleme, CD ya da internet desteği, besteci ve dönem bilgileri, öğretmen eşliği, nota öğrenimi ile ilgili etkinler gibi belirlenen inceleme kriterleri yardımıyla seçilen metotlar incelenmiştir. Bu açılardan bakıldığında her iki çalışmada da farklı piyano metotları incelenmiş olmasına rağmen birbirine yakın kriterlere yer verilmiş olması bakımından çalışmalar benzerlik göstermektedir.

Araştırmanın sonuçlarından yola çıkarak verilen öneriler aşağıda olduğu gibidir:

1) Bastiens' Invitation to Music metodunun Piano Party A ve Piano Party B kitapları genel olarak güzel planlanmıştır ve hedef yaş grubuna uygundur. Bu doğrultuda bu metotların okul öncesi piyano eğitiminde kullanılması önerilebilir.

2) My First Piano Adventure adlı metodun Lesson Book A, Lesson Book B ve Lesson Book C kitapları genel olarak güzel planlanmıştır ve hedef yaş grubuna uygundur. Bu doğrultuda bu metotların okul öncesi piyano eğitiminde kullanılması önerilebilir.

3) Yavuzoğlu'nun hazırlamış olduğu Okul Öncesi Piyano Eğitimi metodu özellikle görsel ve teknik özelliklere çok uyumludur. Müzikal ve teorik özellikler ve gelişimsel özelliklere bakıldığında bazı eksiklikler söz konusu olsa da öğretmen bu boşlukları doldurarak derslere devam ederse güzel bir ilerleme söz konusu olabilir. Sonuç olarak bu metodun okul öncesi piyano eğitiminde kullanılması önerilebilir.

4) Ülkemizde okul öncesi yaş grubuna uygun ve görsel, teknik, müzikal, teorik ve gelişimsel anlamda çocukları olumlu yönde etkileyebilecek şekilde hazırlanmış yeni metotlara ihtiyaç duyulmaktadır. Bu doğrultuda, piyano eğitimcilerine bu çalışmada araştırmacı tarafından hazırlanmış kriterlere uygun yeni okul öncesi piyano metotları hazırlamaları önerilebilir.

5) Piyano öğretmenlerinin okul öncesi yaş grubuyla ders yapmaya başlamadan önce kullanacakları metotları bu çalışmada araştırmacı tarafından hazırlanmış kriterlere göre inceleyip, metotların hedef yaş grubuna uygunluğunu ölçtükten sonra kullanmaya başlamaları önerilebilir.

6) Okul öncesi yaş piyano öğretmenlerine tek bir metoda bağlı kalınmadan, farklı metotlarla ve kaynaklarla iç içe bir piyano öğretim sürecinin ele alınmasının gerektiği önerilebilir.

7) Okul öncesi döneme denk gelen yaş grubundaki çocukların her anlamda ne kadar hassas olduğunun ve bu dönemin ne kadar önemli olduğunun her zaman akılda tutulması ve buna göre davranılması gerekmektedir. $\mathrm{Bu}$ nedenle, piyano öğretmenlerinin okul öncesi dönemdeki çocukların gelişim özelliklerine hâkim olmaları ve öğretmenlerin kendilerini geliştirmeye devam etmeleri önerilebilir.

8) Müzik öğretmenliği kurumlarının programlarında okul öncesi müzik eğitimine ve okul öncesi piyano eğitimine daha fazla yer verilmesi önerilebilir.

9) Okul öncesi müzik eğitimi ve okul öncesi piyano eğitimi üzerine araştırmalar ve bilimsel etkinlikler yapılması önerilebilir. 


\section{Kaynakça}

Arslan, A. (2005). Müziğe başlarken. Morpa Kültür.

Aydoğan, Y., Özyürek, A., \& Akduman, G. (2015). Erken çocukluk döneminde gelişim. Vize.

Banet, B. (1990). Okulöncesi çocuklar için temeller: High/scope yaklaşımı. UNICEF.

Bastien, J. S., Bastien, L., \& Bastien, L. (1993). Invitation to music, piano party A-B, performance party A-B. General Words \& Music.

Bayhan, P., \& Artan, İ. (2007). Çocuk gelişimi ve eğitimi. Morpa Kültür.

Çağlak, T., \& Ercan, N. (2017). Başlangıç piyano metotlarının incelenmesi. Turkish Studies International Periodical for the Languages, Literature and History of Turkish or Turkic, 12(6), 123-136. http://dx.doi.org/10.7827/TurkishStudies.11369

Ertem, A. (2019). Okul öncesi piyano metotlarının erken çocukluk dönemi gelişim basamakları açısından incelenmesi (Tez No. 658585) [Yüksek Lisans Tezi, Gazi Üniversitesi, Eğitim Bilimleri Enstitüsü]. Yükseköğretim Kurulu Tez Merkezi.

Faber, N., \& Faber, R. (2006). My first piano adventure lesson book $A-B-C$, writing book $A-B-C$. The FJH Music.

Güven, D. E., Çevik, D. B., Canbey, E. G., \& Snapper, E. K. (2012). Çocuklara yönelik piyano eğitimi başlangıç metotları üzerine bir değerlendirme. Ĕgitim ve Öğretim Araştırmalarl Dergisi, 1(2), 158-164. http://www.jret.org/FileUpload/ks281142/File/17.guven.pdf

Işıkdemir, B. (2017). 6-11 yaş çocuklara yönelik başlangıç piyano metotlarının incelenmesi ve piyano eğitimcilerinin görüşleri (Tez No. 481783) [Yüksek Lisans Tezi, Pamukkale Üniversitesi, Eğitim Bilimleri Enstitüsü]. Yükseköğretim Kurulu Tez Merkezi.

İman, Y. (2016). Okul öncesi çocuklar için piyano metodu. Arkadaş.

Kartal, H. (2007). Erken çocukluk eğitimi programlarından anne-çocuk eğitimi programının altı yaş grubundaki çocukların bilişsel gelişimlerine etkisi. Ilköğretim Online, 6(2), 234-248. https://dergipark.org.tr/tr/ download/article-file/91011

Kaynak, T. (2004). Okul öncesi çocuklara yönelik piyano metotlarının incelenerek kullanılma durumlarının saptanması (Tez No. 145031) [Yüksek Lisans Tezi, Gazi Üniversitesi, Eğitim Bilimleri Enstitüsü]. Yükseköğretim Kurulu Tez Merkezi.

Öztopalan. R., Gürgen, E. T., \& Özkan, B. U. (2015). Başlangıç piyano kitaplarının müziksel, görsel ve tipografik bütünselliği. Mersin Üniversitesi Eğitim Fakültesi Dergisi, 11(3), 764-780. https://doi.org/10.17860/efd.23095

Uszler, M., Gordon, S., Mach, E., \& Watts, A. (1991). The well-tempered keyboard teacher. Schirmer Books.

Yaşar, Ş. (2009). Okul öncesi ĕgitime giriş. Anadolu Üniversitesi.

Yavuzoğlu, N. (2017). Okul öncesi piyano eğitimi. İnk1lap.

Yıldırım, A., \& Şimşek, H. (2016). Sosyal bilimlerde nitel araştırma yöntemleri. Seçkin. 